\title{
Transportation of Wood Out of the Forest (along Short Distances)
}

\author{
Elisabeth Johann \\ Austrian Forest Association, Vienna, Austria \\ elisabet.johann@aon.at
}

\begin{abstract}
Over thousands of years, man could achieve movement only through muscle power, running water, or with the help of gravity. Transportation was achieved using moving human, animal, or mechanical power. The massive weight of wood and the extensive distances between forest and consumer raised immense problems and were a challenge to the people involved in wood transportation. To facilitate this dangerous and hard labor, wood workers developed various permanent or temporary constructions, which were adapted to their respective local conditions. Over time these have been transformed according to developing technical standards, but they did not change remarkably until the introduction of steam and fossil fuels in the second half of the 19th century. Especially in mountainous regions, forestry was and is dependent on a particularly skilled transportation system. This study examines what locally-adapted technologies were used throughout history to meet the large demand for wood from industry, trade, and the general population, and the kind of organization and planning that was applied. This work focuses on skidding wood out of the forest over short distances, either directly to consumers or to a collection point, from which the transport of large quantities of wood over longer distances started.
\end{abstract}

\section{Keywords}

wood transportation - forest management - protection - forest laws and orders 


\section{Introduction}

Wood (lignum) was the most important source of energy from antiquity until the middle of the 19th century. However, this energy was only available after the felled wood was transported to markets or sites for further working or processing. Thus, problems occurred due to wood's heaviness and the demand for large-dimensions of construction timber as well as the lack of roads and transportation facilities. These problems could only be solved by reducing its weight, which could be accomplished by creating charcoal or by ongoing technical innovations, especially in the transportation of the material. In the 199os, heated scientific discussions, particularly in Germany, tackled the question of whether the high demand for charcoal expressed in laws and orders since the 16th century really existed or was only a manifestation of political power by the ruling landlord (Allmann 1989). From the point of view of mountainous countries, this question did not arise because technical and costly wood transport systems had to be constructed to ensure the energy demands of salt mines and blast furnaces. The local availability of wood was of the upmost importance. Wood abundance and scarcity of wood often existed almost side by side and were determined by the region's topography. Consequently, it was possible that there was an abundance of wood in one valley (if no industry was there and the population density was rather low), but that significant scarcity prevailed in a neighboring valley if they were separated by a high mountain ridge. Meeting the needs of the second valley demanded highly skilled technology. Examples of this include the wood-escalators in Steinbach at the Attersee-lakeshore in Upper Austria or Mariazell in Styria, big dams such the Preszenyklause or Chorinskyklause, or extended grates such as Großreifling or Hallein (see Fig. 1).

Before the 19th century, the transportation of wood was carried out for millennia with the aid of the muscular strength of men and animals, gravity, or hydropower. Thus, the construction of permanent or non-permanent facilities was required, and over time these constructions were continuously adapted to particular local conditions according to ongoing technical innovations.

Particularly in mountainous regions, forest management and harvesting rely on skilled transportation equipment. Therefore, it is important to examine the variety of locally-adapted measures or technologies for wood transportation that have been practiced over time, how these methods met the demands of the wood consuming industry and of local people, and what kind of organization and planning was applied. This study focuses on the transportation of wood out of the forest over relatively short distances and covers the period from the late Middle Ages until the mid-19th century, when the use of fossil fuels sparked remarkable modifications. 


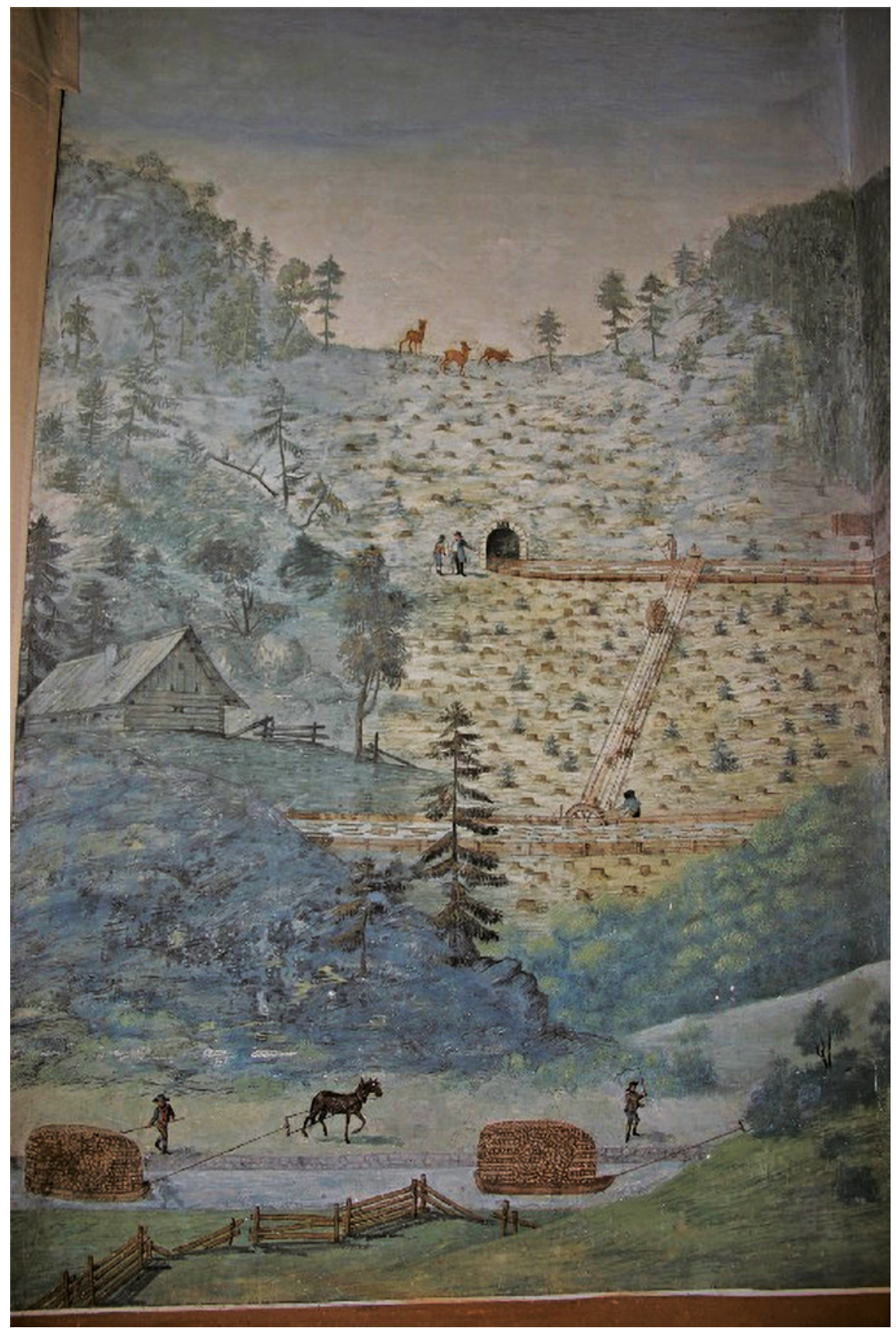

FIGURE 1 Wood-escalator near Mariazell 1830.

SOURCE PATER CHRISOSTOMUS SANDWEGER, FRESCO KLEIN MARIAZELL, AUSTRIA. PHOTO: BRANDL 
This study investigates legislation related to wood transportation throughout history. It relies on regulations directly connected to forest use, as well as regulations related to the protection of man and goods and regulations concerning the increase of efficiency. In addition, reports on technical and organizational innovations and their impacts are taken into consideration. This paper is based on primary sources stored in Austrian archives such as in the Court Chamber Archive Vienna, the House-, Court-, and State- Archive Vienna, and the Carinthia Country Archive Klagenfurt; primary source collections such as those of the Austrian Academy of Sciences (Akademie der Wissenschaften 1881 and 1913); and monographs dealing with the forest history of individual Federal Provinces and regions such as Tyrol (Oberrauch 1952), Carinthia (Johann 1968), Salzburg (Koller 1975a), Upper Austria (Koller 1970, 1975b), and Styria (Hafner 1979). Contemporary paintings and graphics supplement documentation from the 17th century onwards.

The investigated area covers the territory of modern-day' Austria, including both the Alpine region and the Eastern Plains. Depending on the topography, different transportation methods were applied; however, in many cases the legal framework and management methods were similarly designed.

\section{3} Results

In the early years of the Roman Empire there was already a regional and supraregional demand for charcoal and a local demand for fuel and construction wood. Wood and charcoal were transported over long distances, preferably on waterways; for instance, wood from the Alpine region was transported on the river Po to Ravenna or on the river Rhone to Massalia. Attempts to raft the timber on small mountain brooks often failed due to differing water levels and the varying speed of flow along the course of such small bodies of water. Because of its dangerous nature, this work was mostly performed without slaves and was carried out by hired workers. Transportation was often taken over by entrepreneurs (lignari plostrari) (Weeber 2003), and wood was often carried from the forest on small paths (calles, semintae) with the help of carriages pulled by oxen or horses. Paths used for transporting wood out of the forest have always been in use and have been witnessed since the 14th century (Hafner 1994). As long as the iron and salt industries depended on wood, the construction and maintenance of these transport routes were the center of interest. In pre-industrial times, the demand for wood was extremely high. 
In the very beginning, charcoal burning took place preferably where wood was harvested, and the finished product was carried out of the forest on the back or with the help of animals. By the 15th century, small paths and roads facilitated this work. Due to the reduced weight of charcoal, the gradient of these paths was less important than they would be later on, when heavier carriages transported heavier loads of hewn wood. The transportation of round wood out of the forest over short distances is called skidding. This technique was used to bring wood either directly to the consumer for further processing (charcoal burning, sawing) or to collection points installed for the transport of larger quantities of wood over great distances (main runways/slides, forest roads, places for the beginning of rafting operations, forest railways, or aerial cableways).

\subsection{Applied Techniques}

Skidding was practiced with the help of different kinds of permanent or temporary facilities. In steep terrain, gravity did most of the work, whereas in flat or slightly sloped terrain human, animal, or mechanical power was used. For centuries, this work was generally done by horses, mules, or oxen. Such work required experienced and skillful loggers, especially in the mountains. In Alpine regions their work included logging, skidding, and the construction of skidding systems. Knowledge of the job was traditionally passed down from generation to generation. Nearly all of these forestry transport systems were built almost exclusively out of wood, since it was available on-site. The disadvantages were its expensive technology, a short life span, and the practice of large-scale harvesting in one place in order to reduce the costs. This was the reason why this technology became the focus of criticism in the beginning of the 19th century (Hafner 1979).

\subsubsection{Steep Terrain: Skidding Wood by Taking Advantage of Gravity}

In steeply inclined terrains, a particular tool called Zapin helped to start gravity-driven skidding on the ground. Although this procedure caused considerable damage to the transported wood, the remaining stand, and young trees, its simplicity and cheapness made it the favored method since the Medieval period. Skidding was practiced mainly on earthen slides but also over the whole surface of the forest floor. There have been strict and detailed regulations of the use of these slides in place to prevent damage and to avoid accidents since ancient times (Hafner and Trzesniowski 1994, 318-319). Over the course of centuries, several systems developed due to improved technologies. The main types were ground slides (earthen slides), several systems of 
wooden slides, road slides, water slides, and alluvial channels and paths for hand-driven sledges.

3.1.2 Ground Slides (Earthen Slides): Skidding on the Ground

A runway is a slide-like channel built on an inclined slope used to transport felled round wood to a valley with the assistance of gravity (see Fig. 2). This system of transportation is probably as old as humans' utilization of mountain forests.

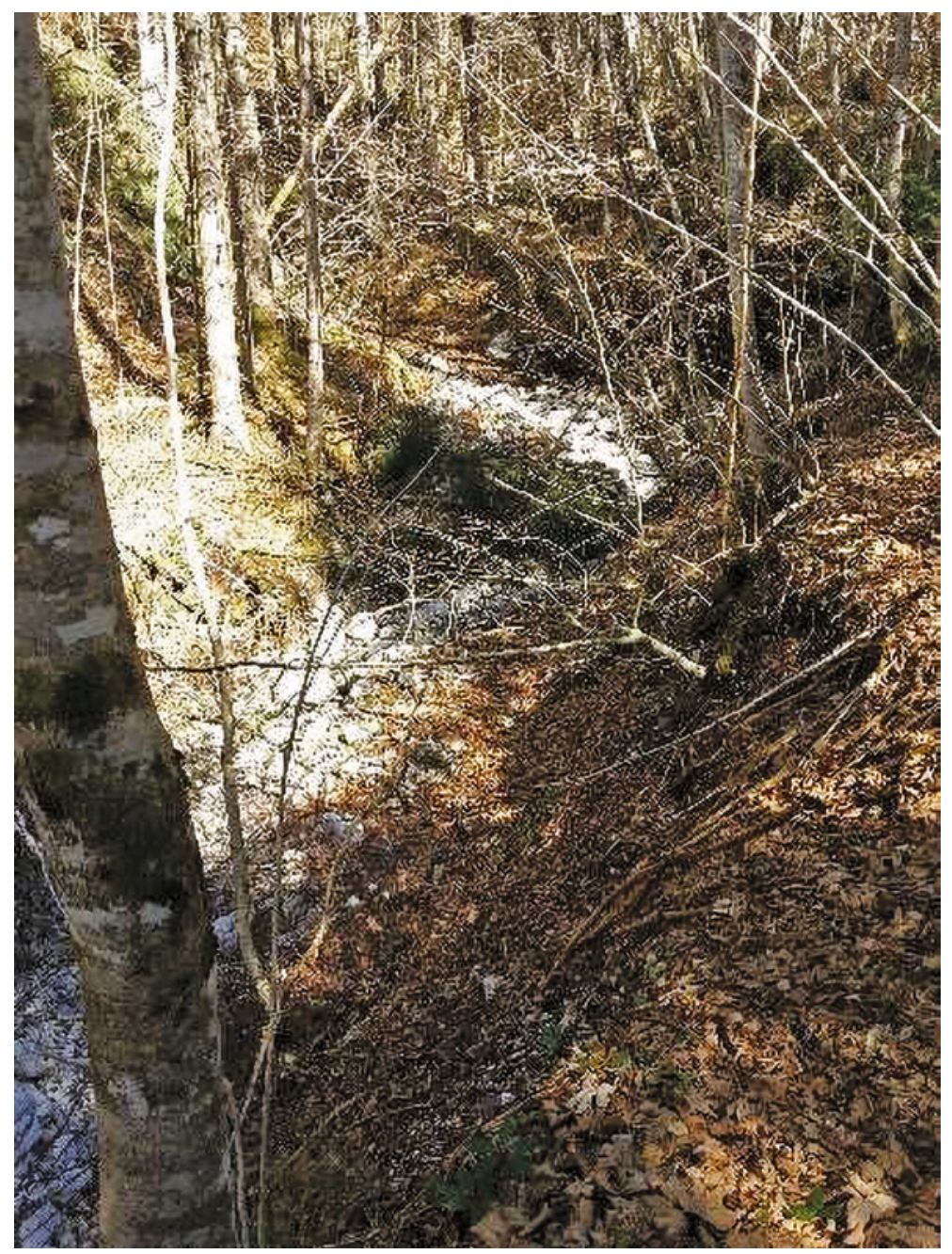

FIGURE 2 Earthen slide, Carinthia, 2oth century.

PHOTO: ELISABETH JOHANN 
Sliding wood down to forest roads was still widely used up until the 197os. It was an important technique for hauling large quantities of wood from areas with difficult access. On steep slopes and during wet weather, round timber could still be transported downhill. Several regulations managed the use of ground slides that were open to the public, particularly with regard to the time of usage (Hafner 1979, 11). Some slides were open year-round, and others only in the wintertime between St. Martin's and St. George's Days. The soil had to be frozen or covered with snow to avoid the imminent danger of erosion and landslides (Hafner 1979, 243).

\subsubsection{Wooden Slides}

The construction of wooden slides goes back to the Middle Ages. They are noted by a sales contract concerning forests, dams, and slides in 1334 (Revers der Halliger zu Aussee) and by the Instruction of Emperor Maximilian I to his forester Sigmund Baumgartner concerning wood-transportation by slides in 1499 (Hafner 1979, 243) (see Fig. 3).

Depending on the gradient of the slopes, different systems existed side by side, such as dry slides, wet slides, snow slides, and ice slides. A further

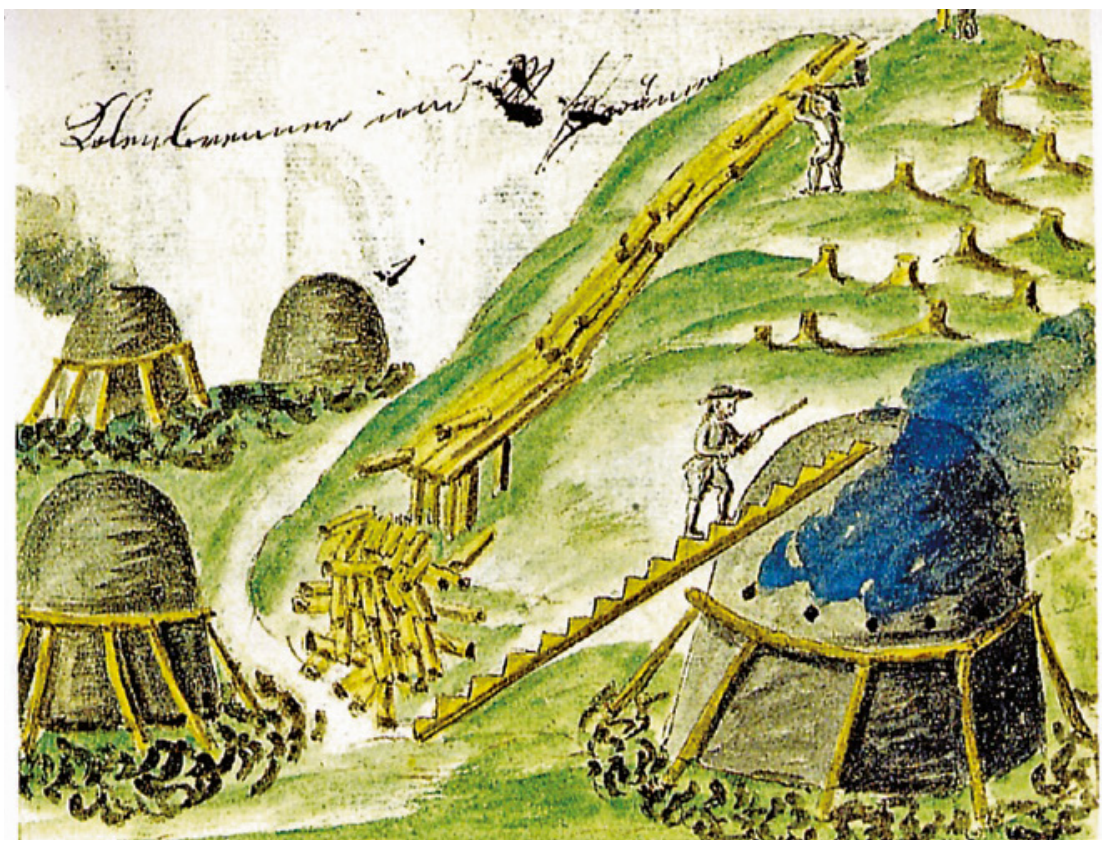

FIGURE 3 Wooden slide, 16th century (Tyrol and Carinthia).

SOURCE: JOHANN (2004) 
differentiation occurred related to their intended use, which included main slides, secondary slides, and slides for logwood piles. Secondary slides were used to transport felled logs from clear cuts to the main slides (constructed for the mass-transportation of wood from large forest stands). The disadvantages of wooden slides were the high construction costs and the great damage to the wood. Wooden slides lasted only 5 to 6 years, thus efficiency required intensive harvesting in one place (causing large clear-cut areas). Sliding was usually included in the contracts concerning felling and trimming (Hafner 1979, 243). The expenses for the construction of wooden slides varied depending on the steepness of the terrain and correspondingly on the type of slide (Wessely 1852, 411). As long as charcoal and fuel were produced, the damage to the wood caused by sliding was negligible; indeed, slides best fulfilled the contract requirements. With rising prices for construction timber of good quality and the replacement of charcoal by fossil fuels, wood slides had many disadvantages (see Fig. 4). Even with these disadvantages, this system was still used, at a very reduced scale, until the 195os.

\subsubsection{Road Slides}

Road slides were a modification and combination of earthen and wooden slides. They were artfully shaped paths with wooden constructions in which timber or wood in longer piles could skid down without much human interference. When the road slides had to cross a gorge, which could not be avoided due to natural conditions, a bridge had to be built to cross it. Road slides were established in the State Forest of Cadino near Cavalese in the Trento region before 1873, and in Upper Austria (Brachberg near Ischl in Upper Austria) beginning in 1879. Other examples were situated in Styria (Ennstal-Riesweg near Hieflau, constructed in 1897), and Waldalm-Riesweg in Palfau (1905). The last road slide was constructed in 1930 in East Tyrol. The advantage of road slides was the fact that less timber was necessary for their construction compared to wooden slides. Skidding season for gradients below $17 \%$ was allowed only in winter with a covering of frost or snow, and for gradients up to $44 \%$ during rainy weather in summer or autumn. For higher gradients, skidding could also take place during dry weather in summer or autumn (Hafner 1979, 245).

\subsubsection{Water Slides and Alluvial Channels}

Waterproof wooden channels resting on piles came into being after earthen slides (see Fig. 5). The first documentation of this method is from the 16th century, when a water slide was mentioned in the area of Arding in Styria and near Nassereit in Tyrol. They are also cited in the Order of Styria oncerning forestry, charcoal burning, and floating, entitled "Wald-, Kholl und Flößordnung 


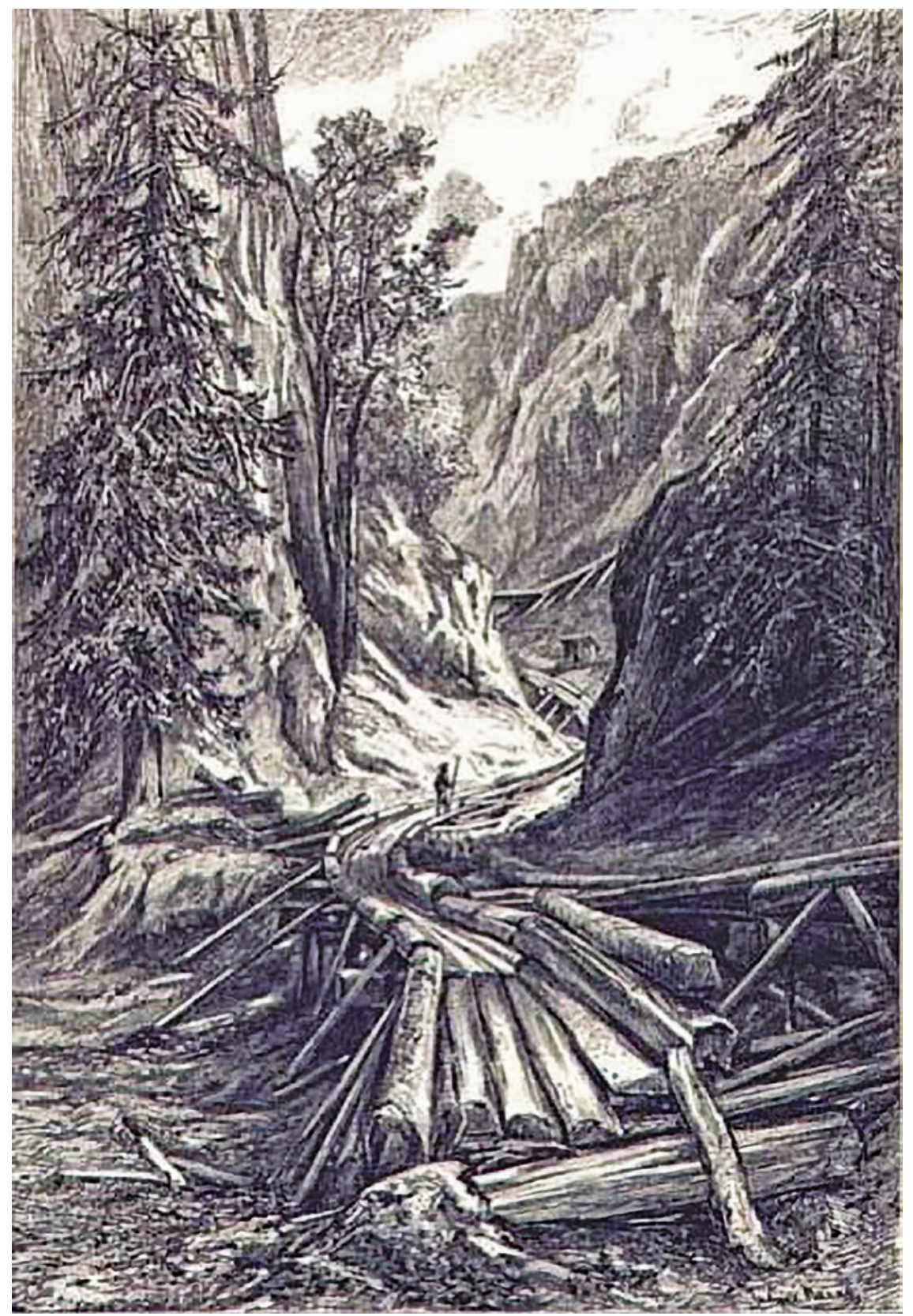

FIGURE 4 Wooden slide, Höllental in Lower Austria, 19th century.

SOURCE: DIE ÖSTERREICHISCHE MONARCHIE IN WORT UND BILD,

BD. NIEDERÖSTERREICH 1888, DRUCK UND VERLAG DER KAISERLICH

KÖNIGLICHEN HOF- UND STAATSDRUCKEREI, 337 


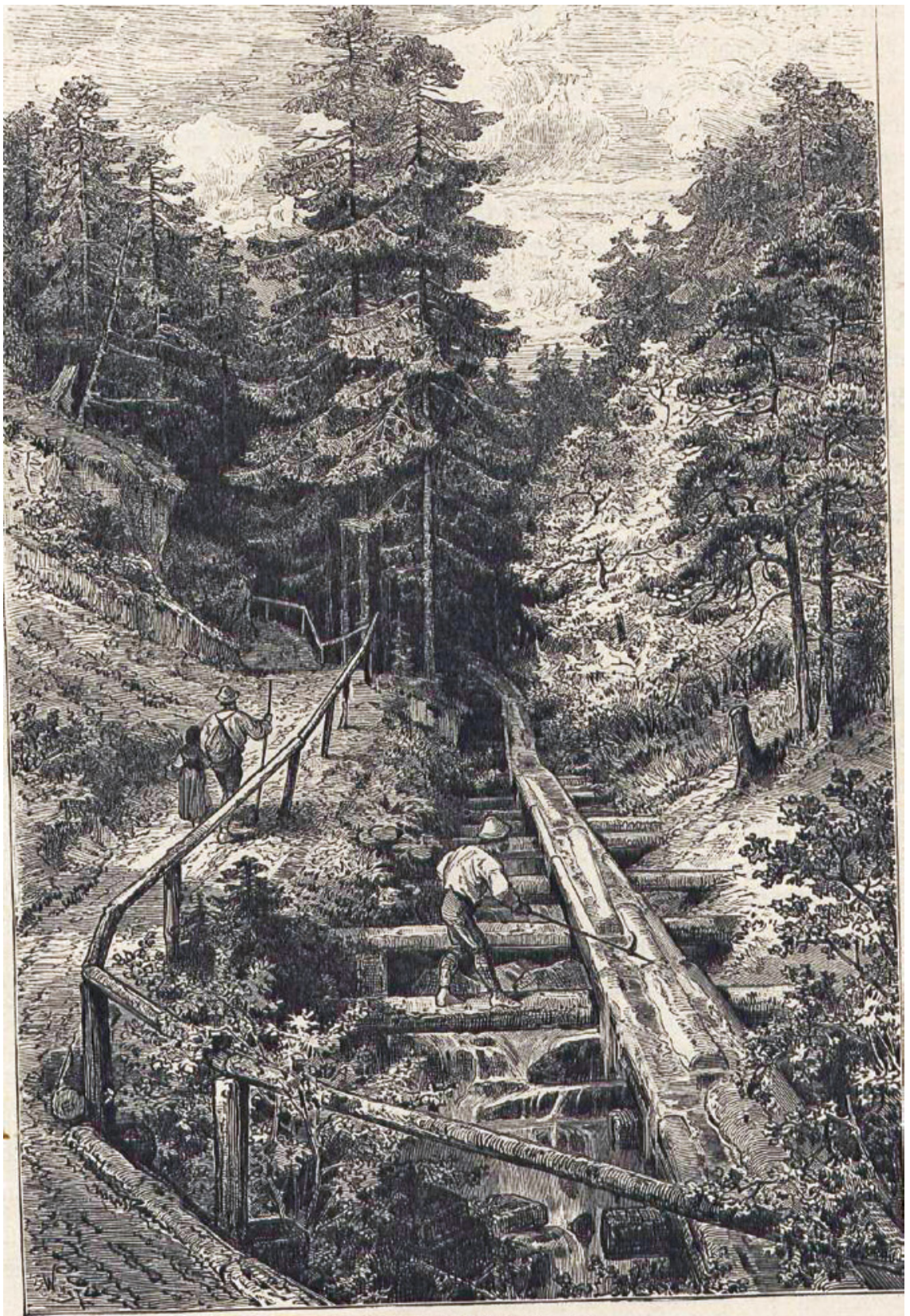

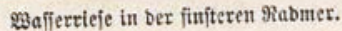

FIGURE 5 Water slide, 19th century, Radmer in Styria.

SOURCE: DIE ÖSTERREICHISCHE MONARCHIE IN WORT UND BILD, NIEDERÖSTERREICH BD. STEIERMARK 1890. DRUCK UND VERLAG DER KAISERLICH KÖNIGLICHEN HOF- UND STAATSDRUCKEREI, 379 


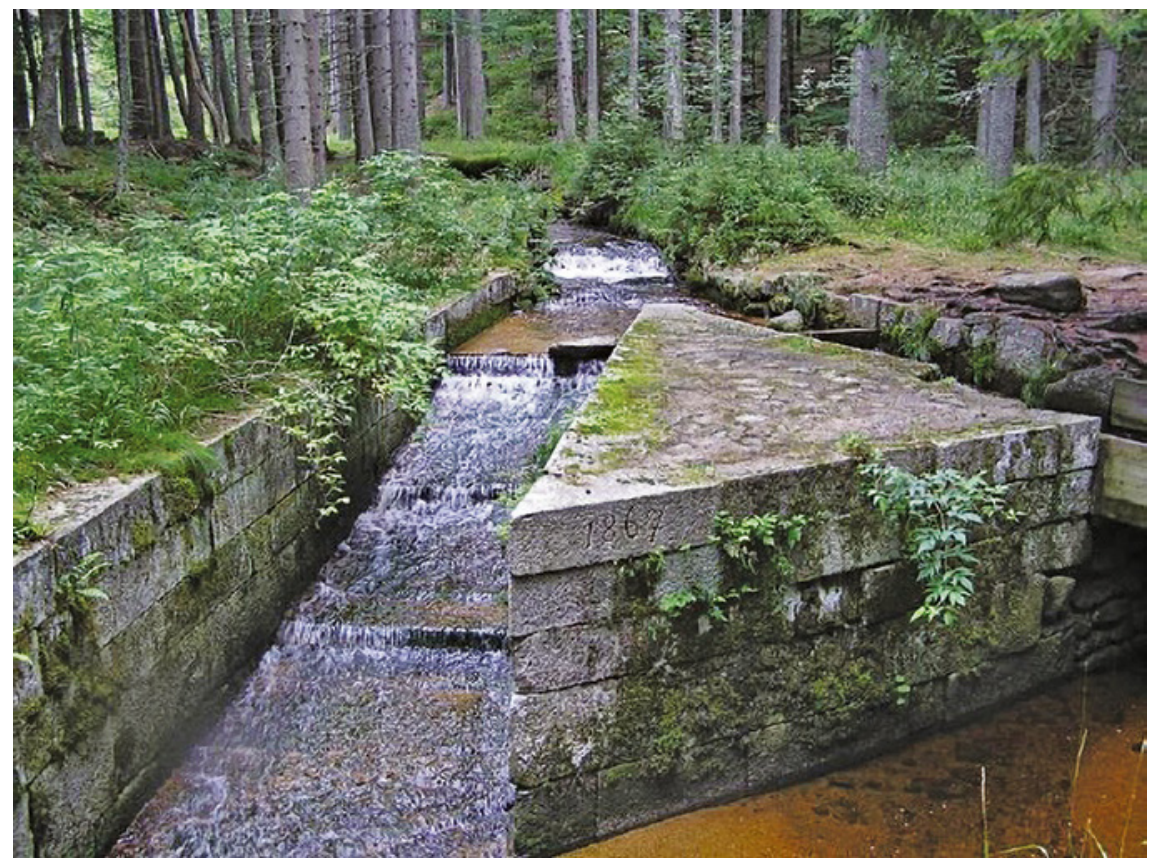

FIGURE 6 Alluvial channel Schwarzenbergkanal, Upper Austria, built by Rosenauer in the 18th century.

PHOTO: GILBERT HOLZER

des Herzogthumbs Steyr," published in 1632 and 1668 (Hafner and Trzesniowski 1994, 324-325).

In water channels, wood did not slide on a surface but was carried by the flowing water. Alluvial channels had a lower gradient than water slides and were built to last for a long time. Their construction was more expensive and involved both more materials and more labor. Their efficiency was demonstrated when the mass transportation of wood was required, such as when the Schwarzenbergkanal was built between 1789 and 1822 (see Fig. 6).

\subsubsection{Paths for Hand-Driven Sledges}

\subsubsection{Permanent Construction}

Paths for hand-driven sledges were in widespread use by the eighteenth century (see Fig. 7). They commonly had a width of 2 to $2.5 \mathrm{~m}$ and were occasionally in use in the Salzkammergut in Styria until 1948. Different types existed with regard to the transport of logwood (or saw timber determined for the production of boards), round wood (any other kind of timber (construction, poles etc.)), or bark. Sledging provided work and a good income for the local people over the winter. 


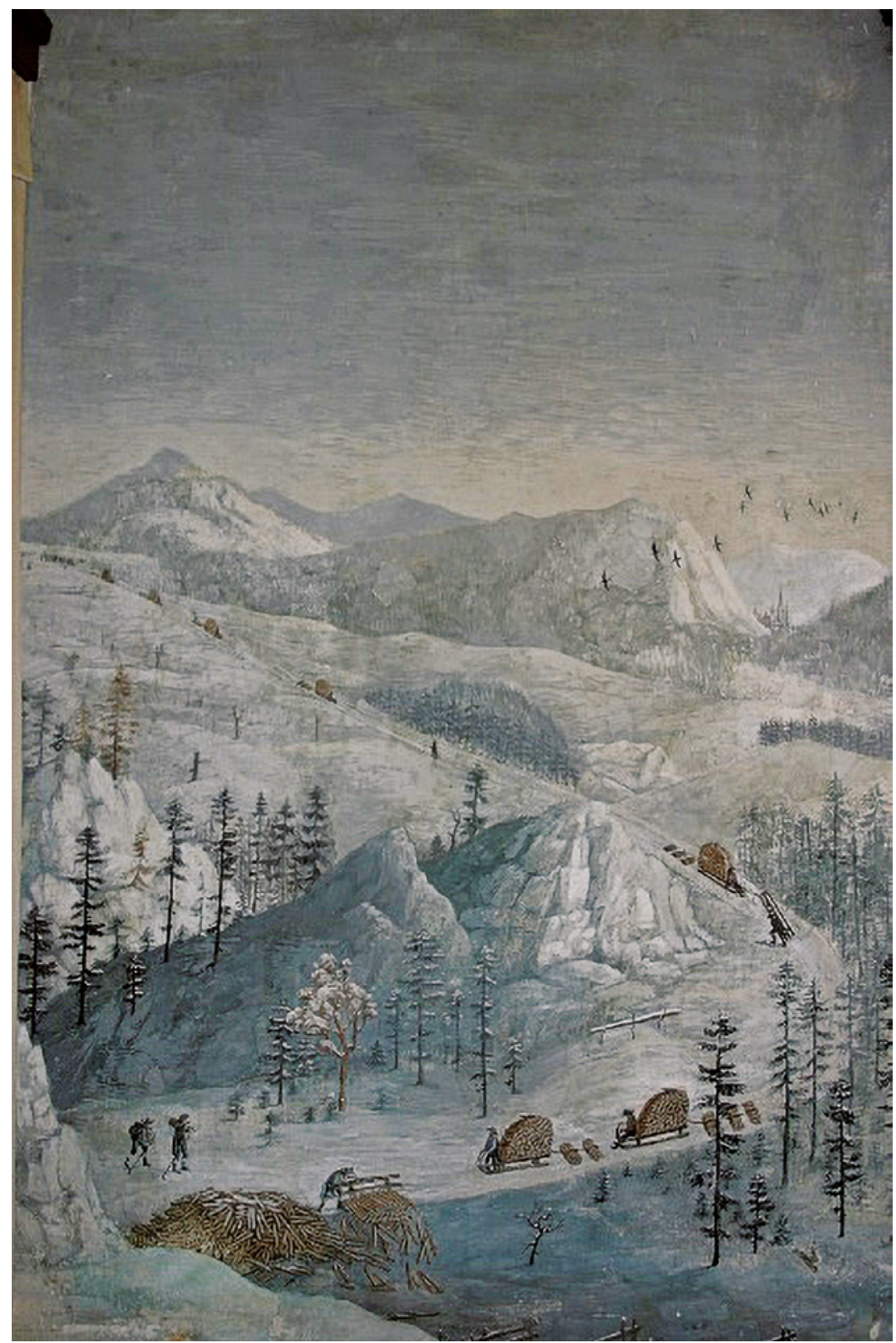

FIGURE 7 Sledging near Mariazell in Styria, 19th century. SOURCE: SOURCE PATER CHRISOSTOMUS SANDWEGER, FRESCO KLEIN MARIAZELL, AUSTRIA. PHOTO: BRANDL 


\subsubsection{Temporary Construction}

Temporary paths for hand-driven sledges, such as those documented in the Koralpe region of Styria, were suitable for transporting wood over short distances during a short period in the winter (see Fig. 8). They were constructed so that any unevenness in the terrain was filled with branches and slash. On this surface, snow was laid and water was sprinkled. The frozen layer then provided an ideal surface for newly fallen snow. In shady valleys, such paths lasted 3 to 4 weeks per year (Hafner 1979, 237-238).

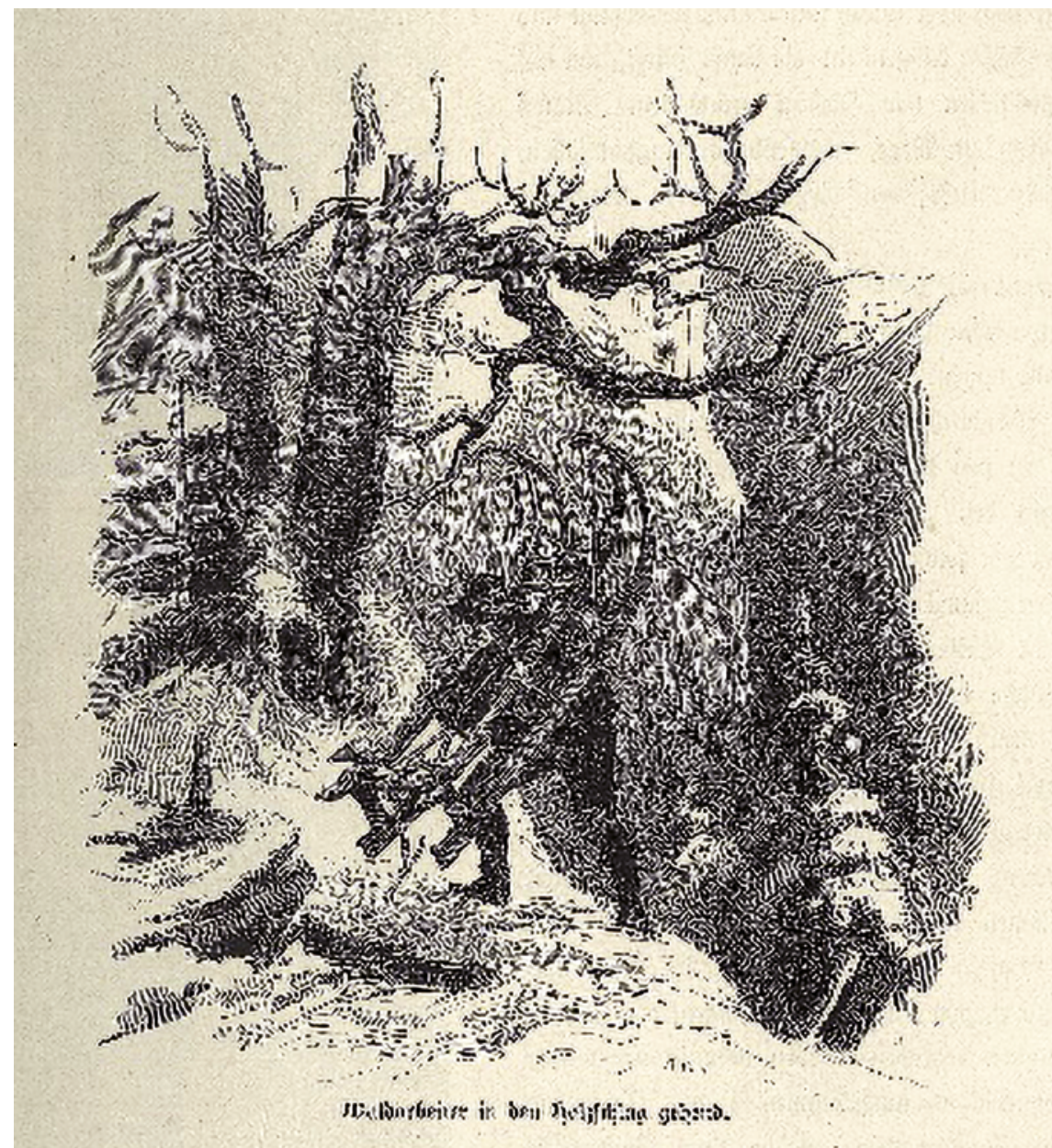

FIGURE 8 Forest worker with a sledge uphill, Styria, 19th century. Graphic Franz von Pausinger.

SOURCE: P.K. ROSEGGER, S.D. WANDERUNGEN DURCH STEIERMARK UND KÄRNTEN. STUTTGART DRUCK UND VERLAG GEBRÜDER KRÖNER; 26 
3.1.7 Transportation in Flat Terrain: By Means of the Muscular Strength of Livestock

3.1.7.1 Mule Tracks

For centuries, many mule tracks existed for the transportation of charcoal to consumers. From the 15th century onwards, and particularly in Carinthia and Styria, there were many tracks and paths used to bring charcoal from charcoal kilns in the forests to iron furnaces and hammer mills, such as the mule track from the catchment area of the Salza across the mountains to the miningdistrict of Erzberg. Traces of some of these tracks are still visible today.

\subsubsection{Hauling Roads}

Hauling roads have been used since the Middle Ages (see Fig. 9). A considerable number of documents prove their existence. In 1325, the Urkundenbuch Chorherrnstift Sankt Pölten provides a reference to a hauling road wide enough for two carriages (Lampl 1891, 273). According to the Banntading zu St. Gallen (Styria), dating to 1508, and the Forest Law of the Manor Wimsbach (Forstrecht der Herrschaft Wimsbach), hauling roads could be used free of charge and without limitation (Hafner 1979, 10).

The 1547 village law of the Heiligenkreuz monastery (Banntaiding des Stiftes Heiligenkreuz zu Baumgarten an der March) did not allow the blocking up of hauling roads open to the general public (Hafner 1979, 338). Here it was

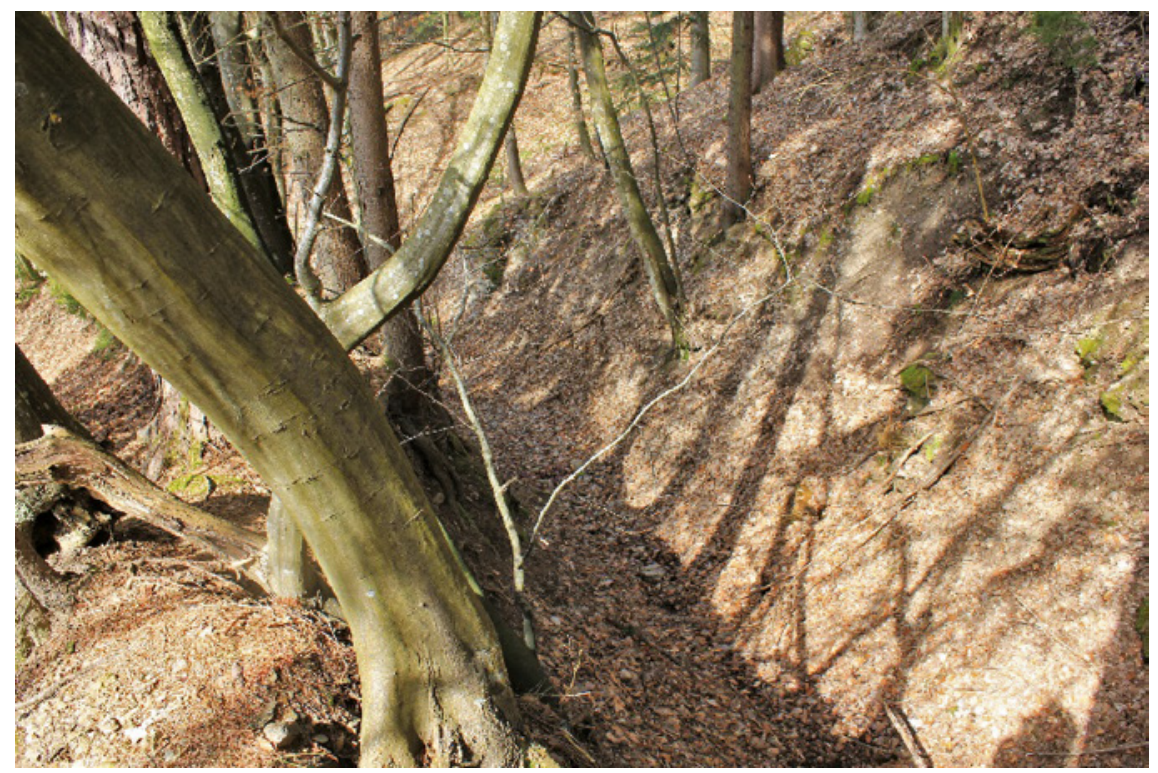

FIGURE 9 Hauling road dating back to the Medieval Period, Christophberg in Carinthia. PHOTO: EWA JOHANN 
forbidden to open new roads and to maintain existing roads, in order to avoid erosion damage. The forester was obliged to close all infrequently used hauling roads in spring (14 days after April 23). The Rights of the Goëss monastery from the 15th and 16th century and of the Manor Festenburg made it illegal to hang pieces of wood on carriages that were used for transporting charcoal. Thus, one could avoid erosion after heavy rain on steep roads (Hafner 1979, 234).

\subsubsection{Log Trails}

These were unpaved roads used for skidding wood to the main forest roads in flat or slightly sloped terrain (see Fig. 10). Building these roads required clearing

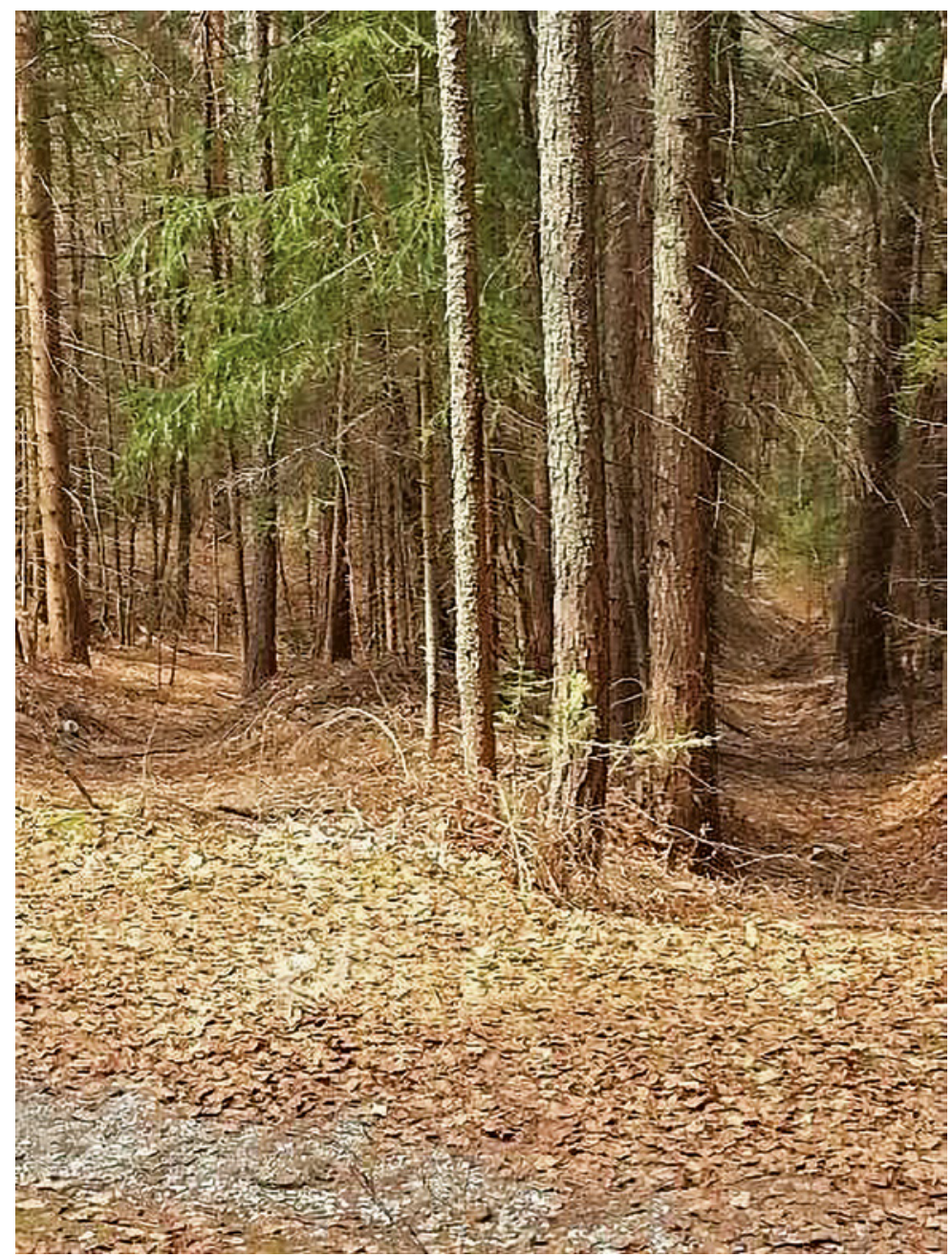

FIGURE 10 Trails for skidding the logs downhill.

PHOTO: ELISABETH JOHANN 
trees, shrubs, stone blocks, and similar hindrances in a route of a designated width. Occasionally, waterlogged terrain and ditches had to be bridged.

\subsubsection{Sledding Roads}

Transportation infrastructure in winter was of great importance until the 195os. It offered work and income to rural populations. Snow provided a good sledge trail after compaction by traffic smoothed out the bumps in the road's snowy surface (see Fig. 11).

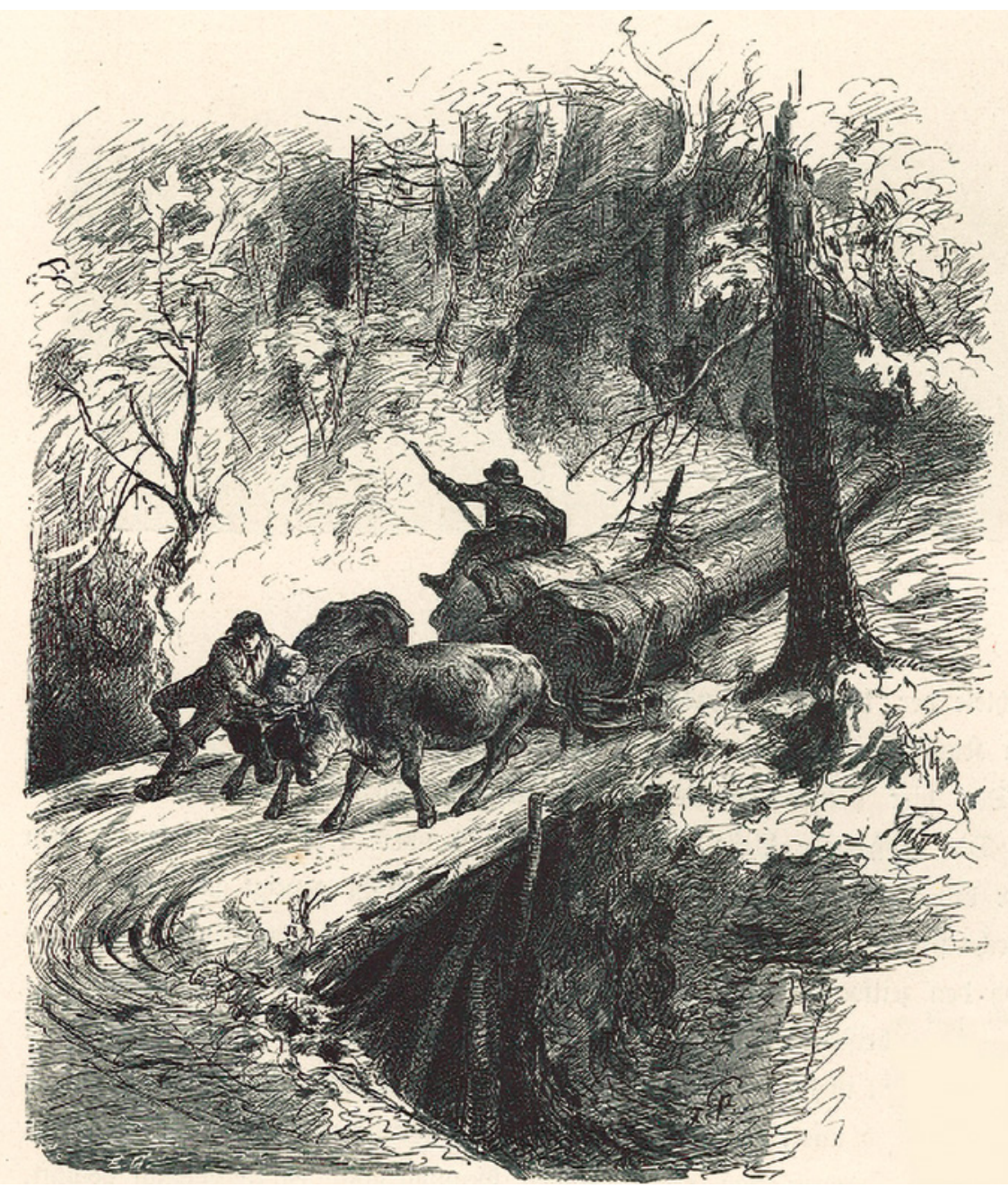

FIGURE 11 Sledging with oxen, Carinthia, 19th century. Graphic Franz von Pausinger. SOURCE: P.K. ROSEGGER, S.D. WANDERUNGEN DURCH STEIERMARK UND KÄRNTEN. STUTTGART DRUCK UND VERLAG GEBRÜDER KRÖNER; 172 
Sledding provided a significantly more efficient mode of transportation in winter, even on what in summer were barely drivable roads. Under appropriate conditions, a chain of logs could be attached to short sledges. In this way, up to $10 \mathrm{~m}^{3}$ of wood per animal could be moved on gradients between 10 and $12 \%$. Horses or oxen, and later tractors, provided the power to move these loads.

3.1.8 Skidding by Hydropower

In the Austrian Alpine region, records from the Late Middle Ages attest to the use of raft constructions. A description of the Salzburg forests from 1530 lists the waterways on which wood could be rafted to Hallein without dams. These waterways were called free streams. Floating with the help of dams was the only possibility to transport wood on small brooks and streams (Koller 1975a, 229-230). Before flowing into big rivers, the wood was stopped by simple grates (booms), such as in the creeks approaching from the Hohen Tauern before flowing into the Salzach. In larger streams with significant woodlands growing in the catchment area, and where rafting activities were carried out annually, larger and more heavily constructed grates were required.

Rafting operations and facilities (dams and grates) were further developed by the Gmunden Salt-Mining Authority (Koller 1975a, 26o) (see Figs 12 and 13). In the region of Salzkammergut, various smaller floating streams existed

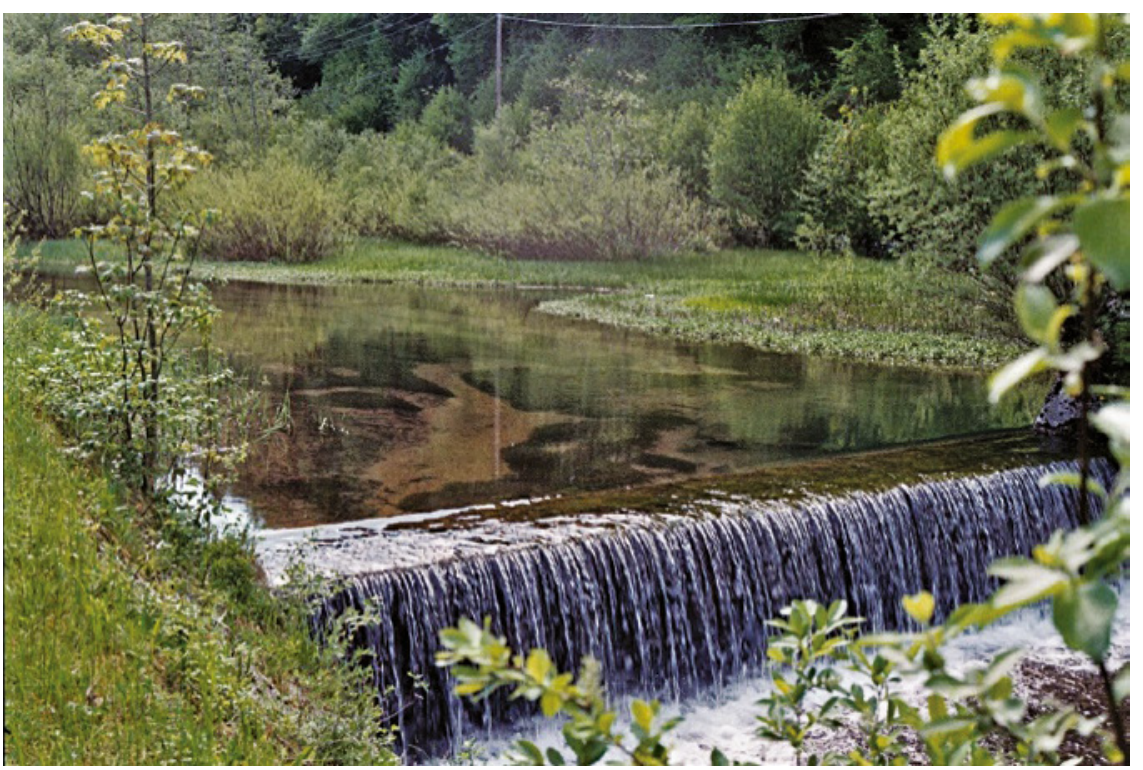

FIGURE 12 Nadasdy Dam, Upper Austria.

PHOTO ELISABETH JOHANN 


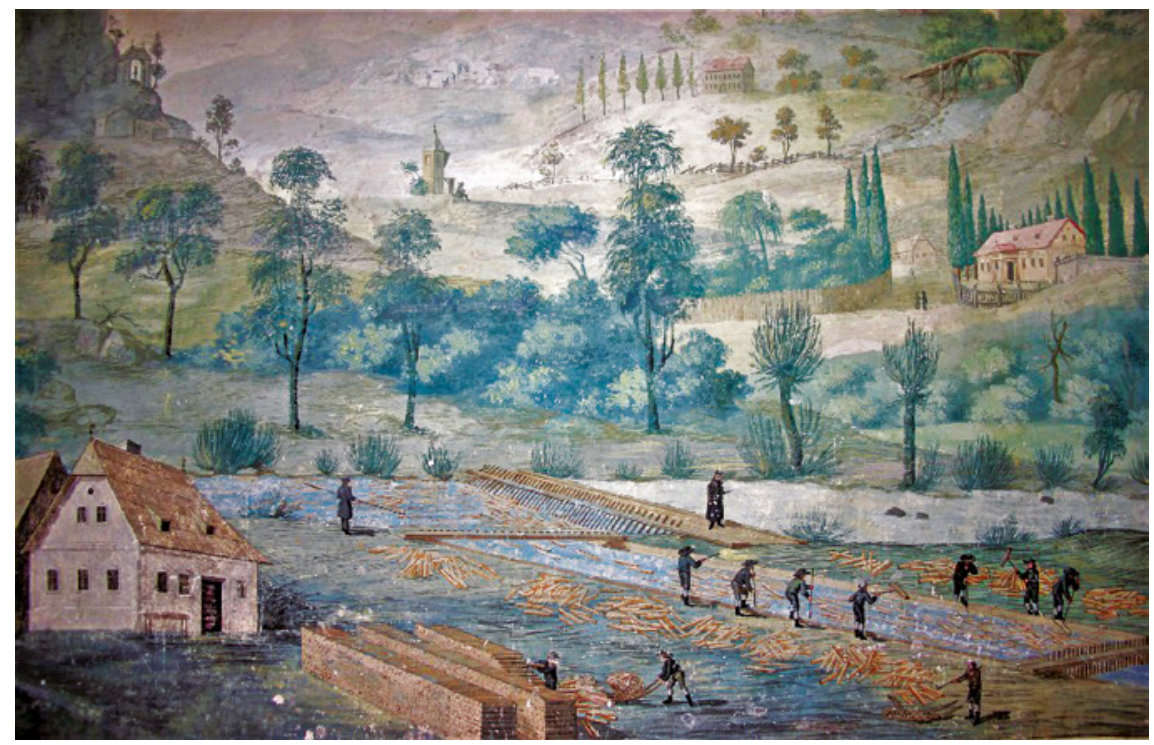

FIGURE 13 Rafting Maria Zell, Styria, 183 .

SOURCE PATER CHRISOSTOMUS SANDWEGER, FRESCO KLEIN MARIAZELL, AUSTRIA. PHOTO: BRANDL

in addition to the large drifting facilities built for the transport of large quantities of wood in the Aussee, Hallstatt, Ischl, Ebensee, Wessenaurach, and Mitterweißenbachtal areas (Stummer 2007, 86-88).

3.1.9 Further Development of the Forest Technique

3.1.9.1 Pole Roads/Forest Railways

The use of railways in forestry occurred much like it did in the mining industry. The dramatically lower rolling resistance of railways allowed the transport of large loads. In 1877, loggers built the first runways on the Gstatterstein, a mountain in Styria. The railway was built to avoid the skidding of wood along a previously used 8oo-meter earthen slide interspersed with rocks. Forest railways became the optimal way to safely transport large quantities of wood and, despite the expense of their construction, were in operation until trucks replaced them. In the 195os, the last remaining forest railways were demolished in Styria (Steinhaus-Rettenegg and near Deutschlandsberg) (Hafner 1979, 239).

\subsubsection{Gravity and Aerial Cableways}

By around 1850 in the Trento area, lighter forest products (such as lumber, firewood, and bark) hanging on a rope with hooks were taken across steep rocky slopes to the valley below (Hafner and Trzesniowski 1994, 327) (see Fig. 14). The 


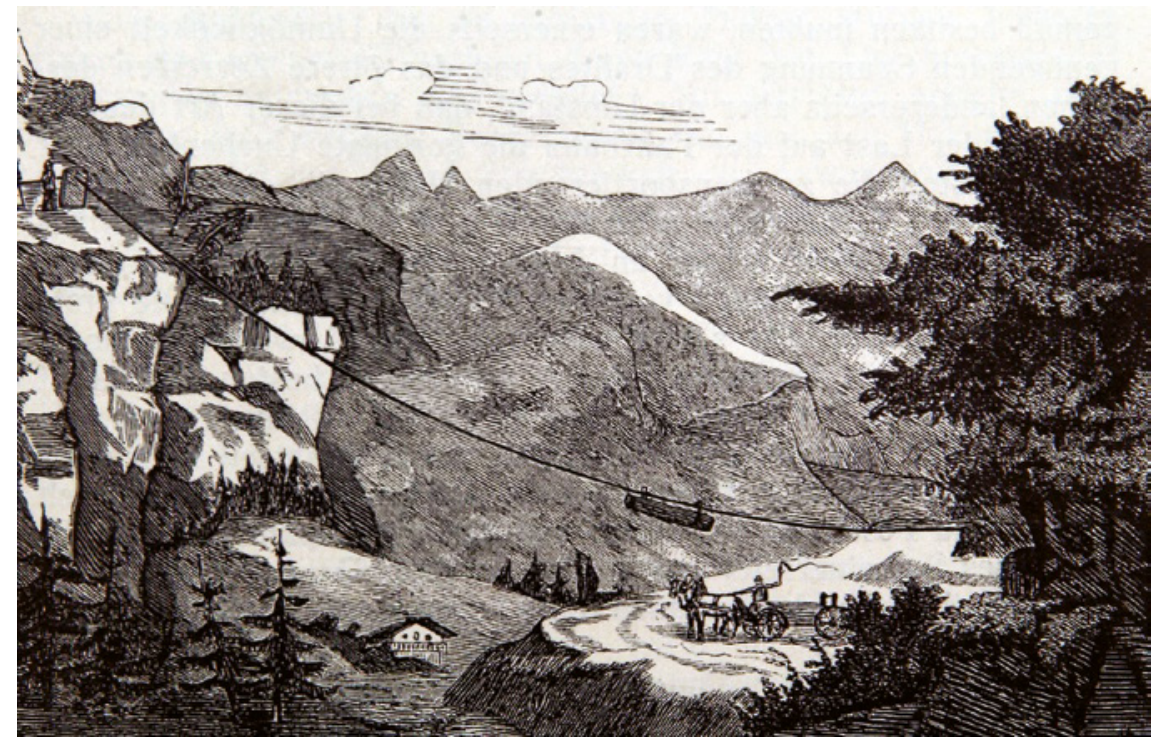

FIGURE 14 First implementation of gravity-driven cableways, Fai, Mezzo Lombardo, Italy 1859 .

SOURCE: FAO LIBRARY. COLLECTION EISENACH

first gravity-driven cableway equipped with a brake started its operation in 1878 in Podkorit and Podblatnik in Carniolia, and the first gravity-driven cableway for long timber was established in 1875 in the Arbedo Valley near Bellinzona. Thus, by the mid- to late nineteenth century, log and timber transportation was by and large unimpeded by terrain or weather. Not until after 1900 did the use of cableway systems with stationary and mobile facilities come into wide use, and they have continuously developed up to the present (Hafner and Trzesniowski 1994, 327-328).

\subsubsection{Extension of a Forest Road Network}

In 1850 , forest road systems had not made much progress compared to rafting systems. However, in 1852, Josef Wessely - one of the most famous scientists, teachers, and practical foresters of his time - promoted the construction of forest roads because of the remarkable rise in the value of timber (Wessely $185^{2}$ ). From the second half of the 19th century on, the building of forest roads has consistently increased up to the present (see Fig. 15). This network of roads enables weather-independent continuous access to the forest for both management and harvesting.

From the 1950s onwards, trucks dominated the transportation of wood over greater distances. This ushered in a system of unbroken transportation over 


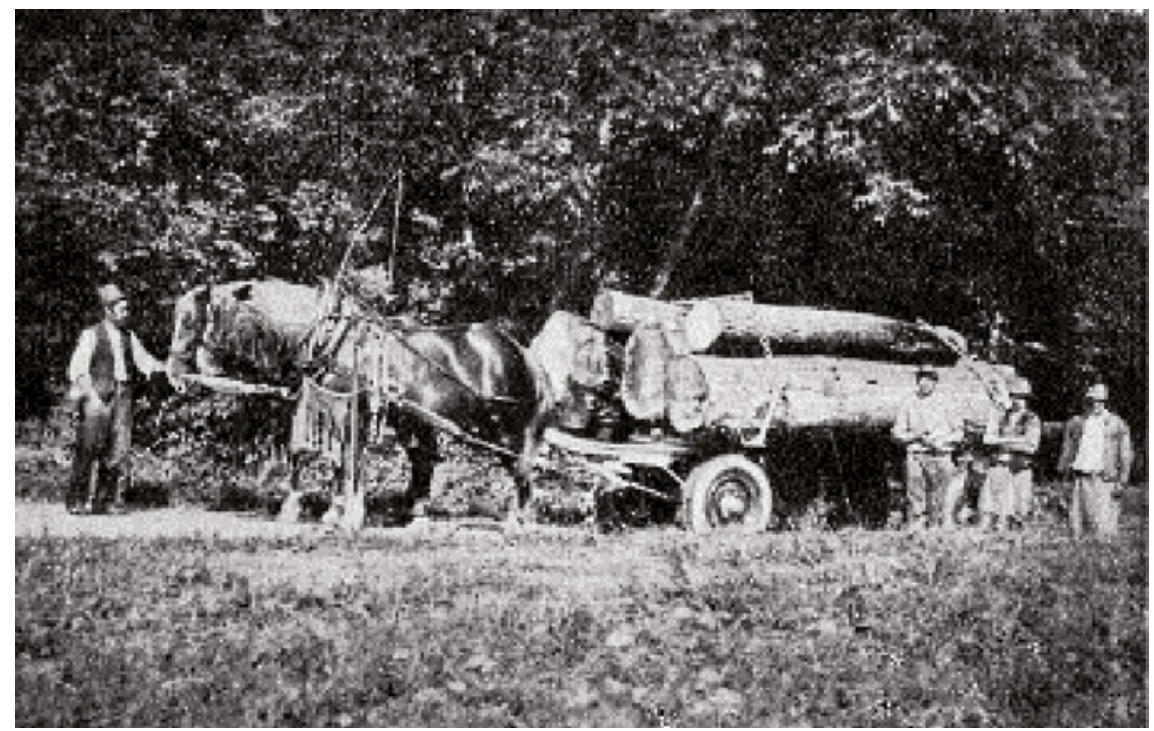

FIGURE 15 Horse-driven transport of wood on a carriage with rubber wheels (1930s). SOURCE: ARCHIVE AUSTRIAN FOREST ASSOCIATION

distances of several hundred kilometers. The older three-way division of transport - skidding, intermediate transportation, and main transportation - was replaced almost entirely by a two-part system of skidding and main transport by logging trucks on forest roads directly to lumber mills. Year-round transportation with short periods between harvesting and processing became common and replaced winter wood skidding. A major step forward brought new machines into the forests after World War II - the caterpillar and the forwarder, which carried logs from the stump to the roadside.

\subsection{Legal Framework of Conditions and Organization}

For many centuries, the felling and skidding of timber were considered one unit in legal and managerial terms. The contracts and wages that employers and employees agreed upon included the felling, trimming, and skidding of wood to the main slides, streams, or forest roads. The goal of all regulations and laws (village laws, forest laws, and forest orders) was to take care of a scarce raw material and to secure the wood supply for their descendants.

A special focus was placed on the organization, planning, and execution of skidding, provisions relating to the conservation of the remaining stock and the protection of people and properties. Despite the great differences in the way logging techniques were applied depending on different topographies, similar legal conditions existed for both flat and mountainous regions. 
3.2.1 Spatial Order in the Forest with Regard to Wood Transportation The utilization of forest stands was largely determined by the possibility of skidding the wood out of the forest, or the weight of the wood. To ensure a sustainable wood supply for the population and to meet the high energy demands of trade and industry, different regulatory measures had to be developed for logging. These had to provide guidance and limitations for both tree cutting and for a reliable system of transport to markets. Other regulations mandated the division of forest stands into compartments based on the goods to be produced - timber for shipbuilding, wood for barrels, and fuelwood for salt extraction - in the Salzkammergut (so-called Schiff-, Kuf-, und Hallholzwaldungen) (see Fig. 16) (Johann 1994a, 99). The Mountain Order of Emperor Ferdinand I in 1553, which was valid for most of the Austrian mountain regions such as Carinthia, Lower and Upper Austria, Styria, and Carniola, stipulated that logging should be carried out in extended compartments (Johann 2004, 220). In this process, the size of the compartment open for logging was chosen based on the capacity of the respective slide, floating stream, or channel (Hornstein 1951, 222).

Another possibility was the division of forests with regard to the difficulty of skidding due to terrain and distance. This was practiced in the state-owned

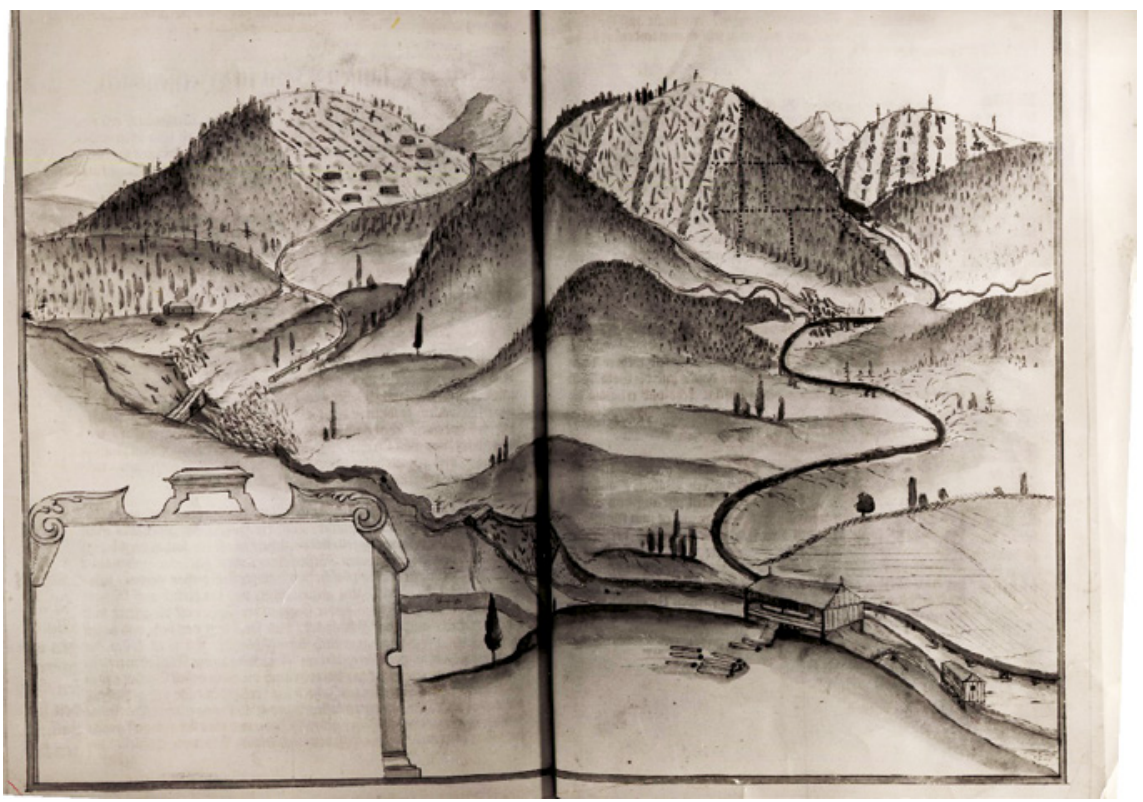

FIGURE 16 Implementation of a spatial order with regard to transportation facilities, Salzkammergut in Upper Austria, 17th century. SOURCE: JOHANN (1994A), P. 98 
forest in the Mölltal Valley in the 19th century (Johann 2004, 658-669). Similarly, the classification of the Imperial Vienna Woods into so-called Achsund Schwemmforste, beginning in the 18th century, provided information about the forest stands suitable for skidding with oxen and horses and forest stands suitable for rafting and/or floating.

These latter forests were of great importance for the fuelwood supply of the Viennese population; however, transportation costs were high, particularly when the logged forest stand was situated far away from a stream. Transport on carts was burdensome because the roads crossing the Viennese Forest, despite a sufficient number surviving since ancient times, were in very poor condition. Forest workers were sometimes specially designated to this particular task of getting fuelwood to Vienna. Annually, each worker had to skid 70 to 8 o cubic meters of firewood from the forest to the roads and further on to the Imperial Court in Vienna. The travel time from the Viennese Forest to the capital was two days and half a night. In 1679, 42 carters, or Duckhüttler, were engaged in this work. In addition to transporting fuelwood from the forest to the Imperial wood barns, they had to skid the firewood to the local alluvial streams (Johann 1979, 227-249).

In 1852, the Empire Forestry Act (Reichsforstgesetz) for the first time provided unified regulations concerning special permits for sliding or skidding on foreign ground (Johann 2004, 639-640). According to this law, each landowner must allow the transportation of forest products across his property that otherwise could not, or only at disproportionate cost, be transported from the forest (see section 2: concerning the skidding of the forest products §24). This was to be done in a way that did the least possible harm to the property, and owners were accorded full compensation for any damage. Anyone could apply for permission to raft bound or unbound wood as well as for the construction of adequate infrastructure. Such requests required special permission (section 26); the maximum duration of such permissions was 30 years.

\subsubsection{Management}

Introducing management plans for skidding over short or long distances grew out of a long history of property owners' complaints. As Wolf Dietrich, Archbishop of Salzburg, complained in the introductory chapter of the Forest Law of 1592, the felling and skidding of wood was carried out without spatial order. Forest workers sometimes skidded wood through the middle of the forest, thereby damaging uncut trees so that they died off or were broken by the wind. In some cases, the wind would pull down all of the mature trees in a forest, damaging the young stands (Koller 1975a, 91). In addition, there were complaints concerning the inept or careless felling of trees that neglected spatial 
order. These problems occurred everywhere in the Austrian Alpine region and led to the enacting of several legally binding regulations. These became part of the Forest Laws published by several Crown lands from the 16th century onward (e.g. the Forest Laws of Salzburg in 1592, Styria in 1695, and Upper and Lower Austria in 1758). These regulations concerned improved techniques with regard to wood transportation (carrying, floating, horse-drawn vehicles, sliding), improvement of the work process and work flow , the time of hauling, the duration of skidding, and the obligation to maintain expensive skidding facilities. Overall, they wanted the workflow under organizational control (Johann 1994b, 174).

\subsubsection{Authorized Workers \\ 3.2.3.1 Authorized Transportation of Own Wood (Wood Supply of the Local Population for Their Own Needs)}

The Village Rights (Dorftaidinge), as they are recorded in Austria since the 13th century, dealt with the wood supply of the local population for their own use. The felling and skidding of timber from the forest were always considered a unit, and the control and prevention of damage to the forest were handled together. To reach this goal, village rights defined the workflow and determined the timing of timber transport from the $15^{\text {th }}$ century onward (Winter 1986). ${ }^{1}$ Villagers had to transport the logs from the forest immediately after felling or within a specified period (Winter 1909). ${ }^{2}$ They were not allowed to store wood within the harvested area, but were allowed to store it beside the road in certain places. These provisions were meant to maintain the road network and ensure resource-saving transportation, while avoiding damage to the young stock and preventing the waste of wood and timber theft. If a woodcutter left the harvested wood in the forest for more than a year, anyone was allowed to take it (Hafner $1979 ;^{3}$ Winter $1886^{4}$ and $1913^{5}$ ) or the local forester was allowed to give it to someone else (Winter 1896$).{ }^{6}$ According to the village right of Netting (Dorftaiding zu Netting in the 18 th century), the villagers had two or three years to skid the wood out of the forest. If they had not removed the wood by then, they had to leave it until the next intended cutting. Then, anyone could take it (Winter 1886). Some rights also stated that wood should

Banntaiding der Herrschaft Araburg, before 1510.

Banntainding des Stiftes Heiligenkreuz zu Winden mid 15th century.

3 Banntaiding zu Wörth bei Neudau 17th century.

4 Bergtaiding zu Wopfing 1746.

5 Banntaiding zu Gutenstein late 15th century.

6 Banntaiding in der Prein 1534. 
be skidded out of the forest stand within 14 days after the felling of the forest and stored in certain places beside the road (Winter 1896, 1909). ${ }^{7}$

\subsubsection{Transportation of Timber and Charcoal Out of the Forest for Industrial Demand}

Because forests close to places of high energy consumption (major cities, industrial areas) had been overused, wood and coal transport became more and more important. While wood was skidded out of the forest using slides, sledding, hauling, and towing by carts or by rafting, often charcoal was carried in sacks on horseback, especially if there were no sledging or other summer paths available. This was the case in the Upper Lavanttal Valley until 1751. There, the main income of the sub-servants came from the profits of charcoal and its transport (Unterluggauer 1925, 126). Additionally, many inhabitants of the Gmünd Manor in Carinthia earned their living by transporting coal to the hammer-mills in Eisentratten. Compensation for the transportation of one bag of charcoal was determined for sleighing as well as for carriage transportation, which earned around $10 \%$ more than bags that were transported using sledging or rafting. However, in 1745 the haulers complained that the wage of $51 / 2$ Cruiser per bag was too little to make a living on. Increased per-bag compensation did not satisfy them. According to the orders for carters implemented by the Gmünd Manor in 1656 and 1663 , not everyone was permitted to carry wood and charcoal (Johann 1968, 111-113). According to the parts of this order solely concerning skidding, only a certain number of carters and vehicles were approved for a particular forest. Often a timetable specifying the permitted days and hours was set up for specified routes, which had to be followed regardless of weather conditions. Only calibrated cribs were admitted. Considering the dense traffic on the narrow sledge trails caused by 19 carters with 49 pair of oxen in 1656 , these regulations were necessary to secure an uninterrupted supply of charcoal from the neighboring forest to the manor-owned ironworks in Kremsbrücke. The costs of charcoal transportation were calculated by the individual enterprises, since they constituted a significant part of the production costs. The individual haulers had to settle their accounts and commitments at the end of the year to receive any surplus or determine their loss because employees received part of their wages in goods in addition to the cash promised them.

7 Banntaiding zu Thern 15th century, Banntaiding des Klosters Garsten, first half $15^{\text {th }}$ century; Banntaiding des Klosters Garsten first half ${ }_{15}$ th century; Banntaiding des Klosters zu Wilhelmsburg first half 15 th century. 


\subsubsection{Logging and Skidding as an Inseparable Unit}

This kind of energy supply was based on an agreed contract, such as that between the management of the Hallein salt mine in Salzburg and the loggers who consequently became independent entrepreneurs, the so-called Holzmeister (woodmasters) (see Fig. 17) (Koller 1975a, 106).

Specific prescriptions in the agreements aimed at avoiding damage to the remaining forest stands. Thus, the felling area had to be totally cleared. The construction of dams for driving timber, slides, and other transportation facilities were also part of these contracts. They were constructed at the expense of the woodmasters (Holzmeister), as was the protection of the farmland situated along the floating streams. The commitment referring to the maintenance of logging buildings lasted until the end of harvesting in the allocated forest compartment. Work was to be performed according to weather conditions, and young trees should not be damaged. Difficult skidding conditions should be enumerated and identified in the contract. One of the most important topics in the contract was that the woodmaster was liable for his belongings for the fulfilment of the contract. Usually the contracts concerned the logging and skidding of wood to the banks of the river Salzach, which was suitable for rafting and floating.

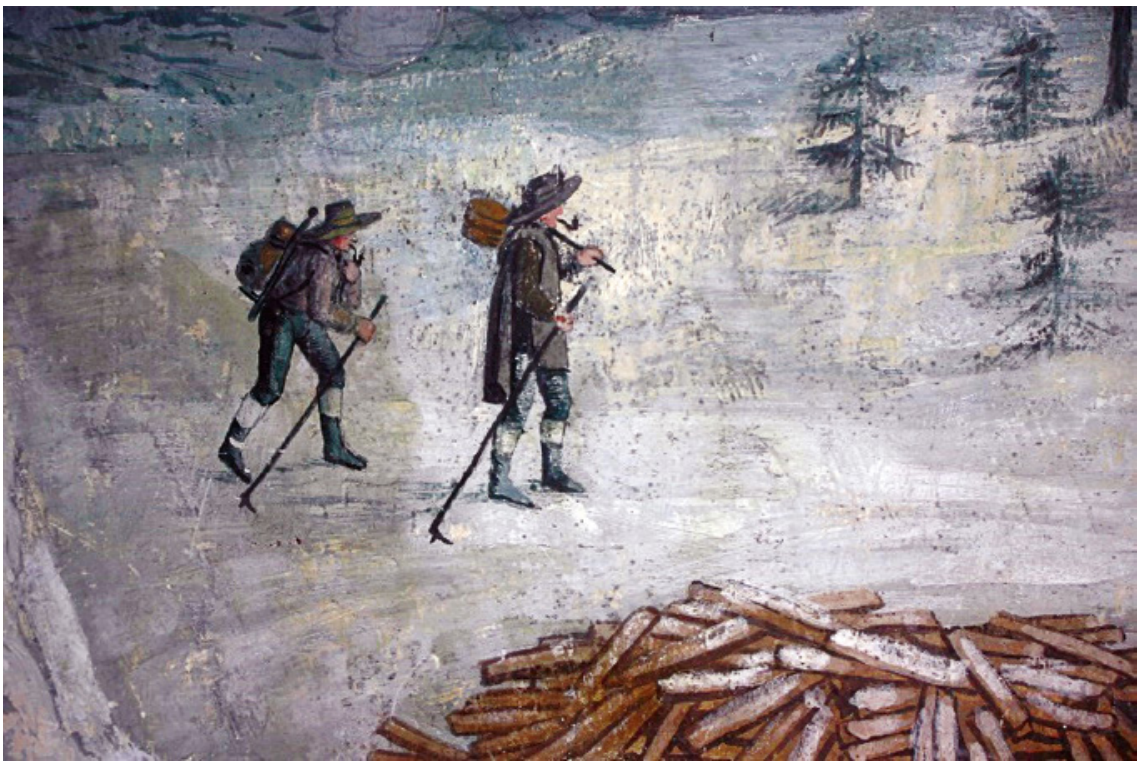

FIGURE 17 Wood workers responsible for logging and skidding, Styria, 1830. SOURCE: PATER CHRISOSTOMUS SANDWEGER, FRESCO KLEIN MARIAZELL, AUSTRIA. PHOTO BRANDL 


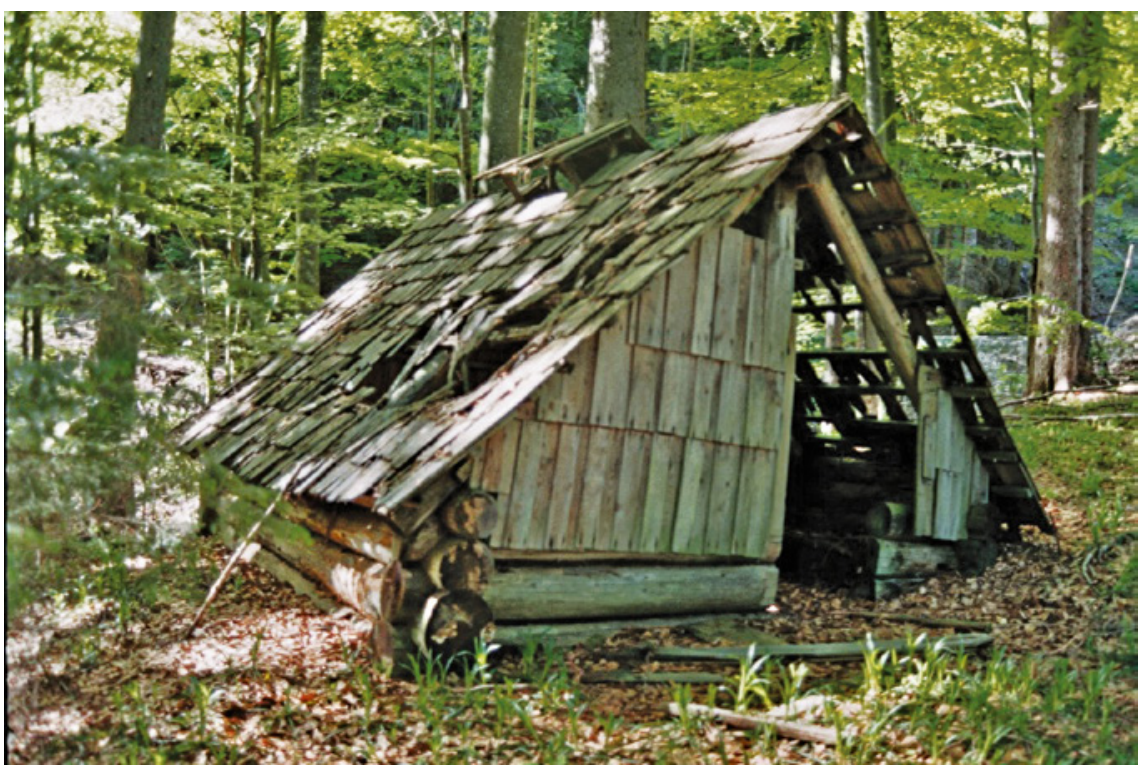

FIGURE 18 Remnants of a wood worker's hut, Upper Austria.

PHOTO ELISABETH JOHANN

The components of these contracts that were practiced between 1830 and $185^{\circ}$ were tied to different steps in the logging process, which were closely interrelated. They concerned the construction of the logging hut, the logging itself, the pulling together of the wood, and the piling up of wood (see Figs 18 and 19). The agreement also referred to the transportation of wood via earthen slides to the main slide, the construction of the slide, putting logs into the slide, and ways to make the logs glide. The contract also obliged the entrepreneur to construct and repair sledge roads. Sledging and skidding with hydropower as well as the piling up of timber along the streams (before floating) were part of the agreed task.

Depending on their progress, woodmasters received appropriate advances on the negotiated price. Difficult transportation conditions had to be taken into consideration when the contract was worked out. Major clear-cuts that lasted for several years had to be settled each autumn to cover the executed work.

In summary, it is important to note that there were no permanent staff employed by the salt mine in Hallein for felling and skidding at the beginning of the 19th century. The work was carried out by independent entrepreneurs (Holzmeister), who were paid for their work based on contracts. These contracts concerned the cutting as well as the transportation of wood, and the 


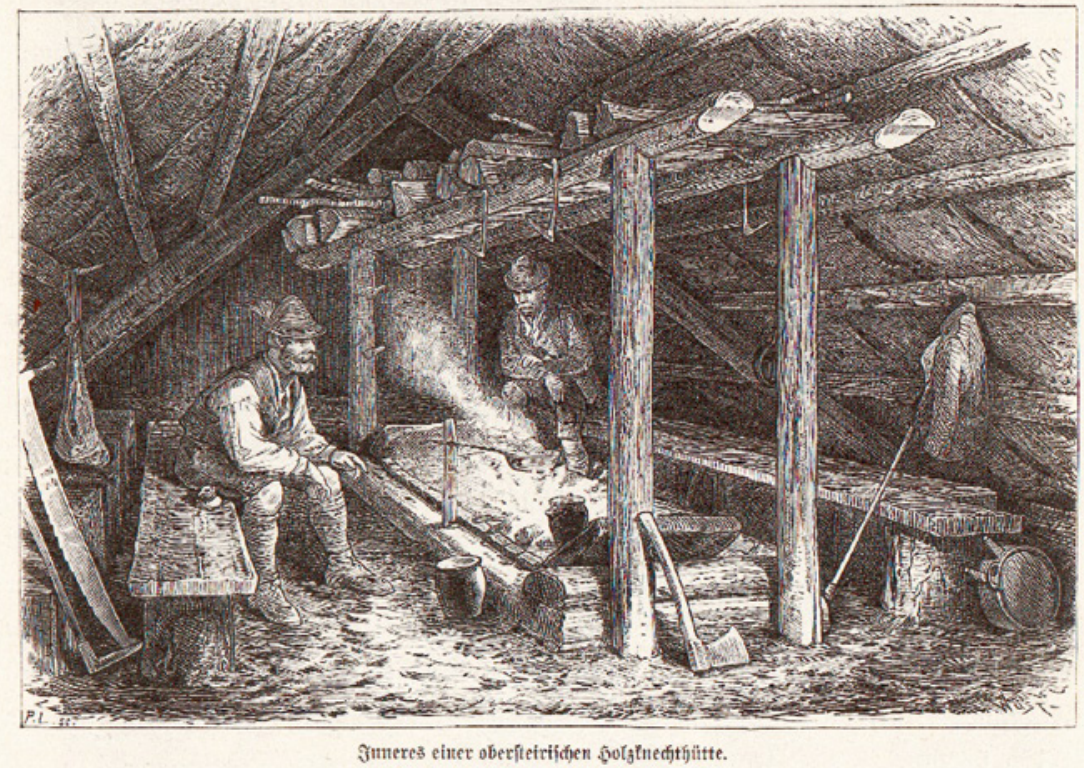

FIGURE 19 Interior of a woodworker's hut, Styria, 19th century. SOURCE: DIE ÖSTERREICHISCHE MONARCHIE IN WORT UND BILD, BD. STEIERMARK 1890. DRUCK UND VERLAG DER KAISERLICH KÖNIGLICHEN HOF- UND STAATSDRUCKEREI, 377

rafting of wood over certain distances down to the main streams. On main streams and rivers, rafting and floating was performed by employed workers under the supervision of the salt mine administration (Koller 1975a, 182). The contract was settled with the woodmasters, who had to acquire the required loggers independently.

\subsubsection{Temporary Limitations of Felling and Skidding}

The felling and removal of wood were tied to specific time limits. These limits were aimed at preventing unlimited forest work by the locals all year round (Hafner 1979, 8-15).8 According to the village rights of the eastern lowlands (Lower Austria), the timespan when the removal of wood was permitted was strictly regulated. It was usually the period from St. Michael's Day to St. George's Day. Afterwards, no one was allowed to go into the floodplain for the rest of the

8 Banntaidings-Artikel der Herrschaft Festenburg 1675 . 
year (Winter 1886). ${ }^{9}$ Sometimes regulations also differed for various types of villagers who owned forest rights, such as farmers or the owners of sawmills (Winter 1913). ${ }^{10}$ In general, the forester locked the forest and the forest roads 14 days after St. George's Day (Hafner 1979, 8-15), ${ }^{11}$ (Winter 1886). ${ }^{12}$ Trespassers were prosecuted.

With respect to the production of charcoal, the Forest Law for Styria in 1567 proscribed the felling of wood until 25 July, or until 10 August as the latest date for the waning moon (so that logs could dry sufficiently). In autumn, logs had to be removed from the felling area and brought to the floating streams where they were piled up. Drifting was carried out in the spring, when the amount of water was sufficient. The felling of firewood for the salt mines had to start in the spring with the melting snow and lasted until October. The logs had to be piled up in areas that had already been harvested. In autumn, slides and sleighroads were to be constructed to skid the wood down to the slides. In winter, the logs were transported by ground slides, sledging, or with horse-drawn sleighs (Hafner 1979, 148).

\subsubsection{Maintenance of Transport Facilities (Roads, Bridges)}

Cart paths in the forest had to stay empty and could not be blocked with wood (Hafner 1979, 8-15). ${ }^{13}$ All logs had to be carried out from the felling area; nothing could remain in the water or on the trails (Winter1886). ${ }^{14}$ Shrubs growing along the paths had to be removed to ensure the proper flow of water run-off (Hafner 1979, 8-15). ${ }^{15}$ Paths usually had to be maintained and repaired by farmers or local communities (Winter 1886). ${ }^{16}$

According to the Forest Law of Salzburg from 1659, farmers were traditionally obliged to provide wood from their forests for the construction and repair of bridges, paths, and walkways (Koller 1975a, 112). Because many paths and bridges were in such bad condition that they had to be completely rebuilt, the Forest Law published in 1592 by the Archbishop of Salzburg stipulated that farmers had to check these paths and bridges more often and must carry out

$9 \quad$ Rechte des Stiftes Klosterneuburg und der Leute in Amt und Dorf Eipeltau 1512; Banntaiding zu Meidling und Hietzing, end 16th century; Rechte und Banntaiding zu Wülfleinsdorf an der Leitha 17 th century.

10 Banntaiding der im Wald berechtigten Nachbarn zu Laimbach 1600.

11 Gerechtigkeit und Banntaiding des Stiftes Heiligenkreuz zu Baumgarten an der March 16th century. Banntaiding des Stiftes Heiligenkreuz zu Winden mid 15th century.

12 Banntaiding auf der Feste Klamm um 1540.

13 Markt Aflenz, Marktgerichtsprotokoll 1636.

14 Banntaiding zu Stolzenwert 16. Jh.

15 Banntaidings-Artikel der Herrschaft Festenburg 1716.

16 Dorftaiding zu Willendorf 156 o. 
repair work immediately. Those who were obliged to maintain the roads and bridges but neglected maintenance were threatened with penalties (Koller 1975a, 131). When the residents of Hennersdorf (Village Right of Hennersdorf around 1530) worried about the conservation of timber necessary for these repairs, they forbade the cutting of trees and fruit trees growing on common land because they were needed for the improvement of the road (Winter 1886).

\subsubsection{Protection of Human Beings and Properties}

Skidding has always been a dangerous job, and many have lost their lives doing it. Therefore, there have been rules that worker should avoid risks to life and property since Early Modern Times.

When timber was carried down in an earthen slide above a public road, guards had to guarantee security during the transport of the wood. When danger was approaching, the guards were to call out warnings (Johann 2004, 209). ${ }^{17}$ For three hours before using a public earthen slide, the woodworker had to shout: "if someone is there please take care" (Hafner 1979, 8-15).18

Under the forest law of the Seisenburg Manor in Upper Austria published in 1623, everyone who used an earthen or ice slide had to shout three times with a loud voice before he threw a piece of round wood into the slide, so that those who worked nearby could easily hear it. However, in case of damage to people or livestock, he was punished all the same. There were similar orders in the Village Laws for Laudegg (1548), Reichenau an der Prein (1537), Wenns (1782), Sarnstein in Lower Austria (1587), Stolzenweit (16th century) and Stans in Tyrol (1636) (Hafner und Trzesniowski 1994, 319).

Everyone had to protect their own property as well as that of their neighbors. People were obliged to avoid direct or indirect damage to crops or fields. This could happen through the interruption of natural runoff by the destruction of the paths and roads (see Fig. 20).

Skidding wood across neighbors' fields or meadows was not allowed because of the resulting damage (Johann 2004, 209) $\cdot{ }^{19}$ Damage caused by wood transportation on trails, roads, or land was to be avoided or repaired. In case a road or bridge owned by the community was damaged due to hauling, it must also be repaired (Hafner 1979, 8-15). ${ }^{20}$ Some roads were in use only within a certain time span (between 11 November and 23 April). In some regions, it was

\footnotetext{
17 Ortenburger Taiding 1389.

18 Weistümer zu Pfunds/Tirol 1303 and Schwarz 17th century.

19 Ortenburger Taiding 1389.

$20 \quad$ Landtaiding des Landesgerichts zu Windisch Matrei 17th century.
} 


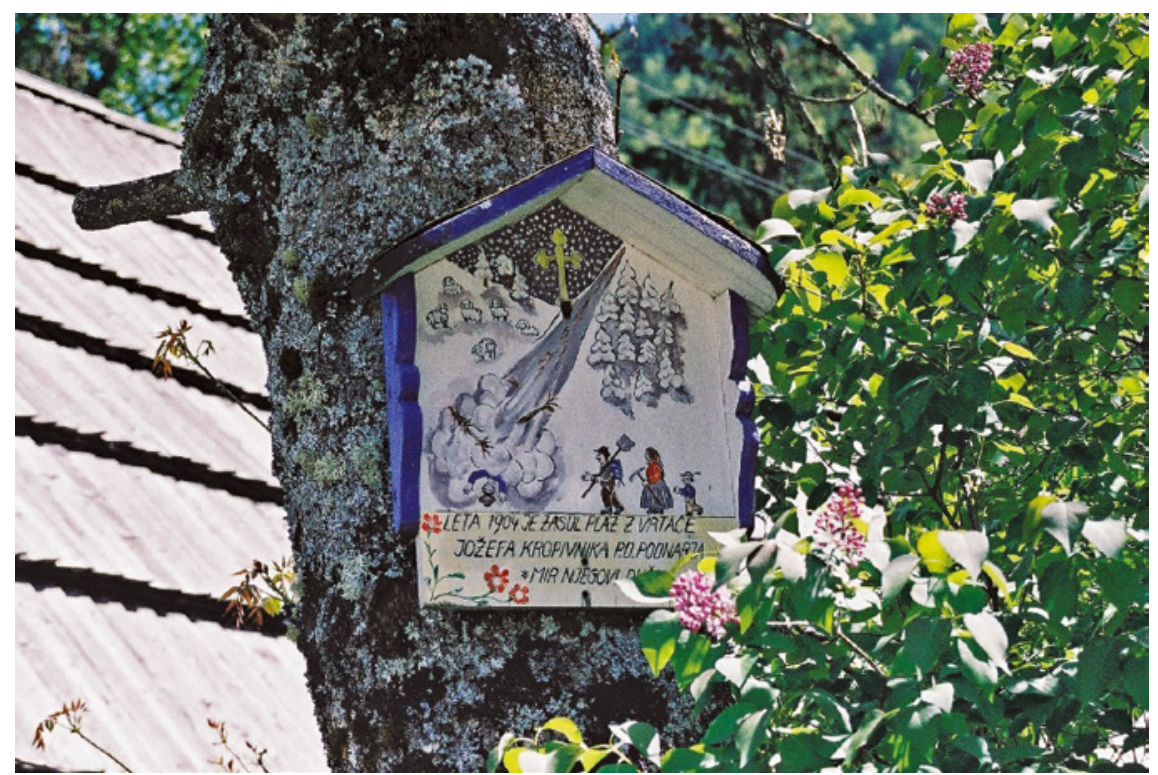

FIGURE 20 Memorial referring to an accident caused by an avalanche, 1904, Carinthia PHOTO: ELISABETH JOHANN

forbidden to open new slides and roads without permission because of mud and rock slides and general erosion (Hafner and Trzesniowski 1994, 319). ${ }^{21}$

Natural hazards and heavy rain exposed roads to erosion, especially in the mountains. The Forest Laws of Salzburg from 1563, 1659, and 1713 prescribed that trees growing immediately above and below roads had to be safeguarded to avoid landslides. Shrubs and hardwood had to be conserved for the purpose of road and dam repair. Several village laws, such as the Weistum von Ries in 1491 or Klamm in 1534, focused on the avoidance of flood damage (Koller 1975a, 131). Therefore, woodworkers were to empty streams, roads, and earthen slides of slide timber when work had been finished (Hafner and Trzesniowski 1994, $319) .{ }^{22}$ In general, to minimize the damage, logs should be skidded downhill to the floating streams on snow or ice slides, on public earthen slides, ${ }^{23}$ or on frozen snow ${ }^{24}$ (Hafner and Trzesniowski 1994, 319).

\footnotetext{
21 Weistum von Salern und Vahrn bei Brixen, Südtirol 16th century.

22 Land- oder Ehaft Taidingen in der Rauris 1565 and 1624; Weistum von Ries, Tirol 1491; Banntaiding der Herrschaft Klamm 1534, Waldordnung des Hof- und Ebenseeamtes Kloster Traunkirchen/Oberösterreich 1620, Forstrecht der Herrschaft Sarnstein, Oberösterreich 1587 .

23 Landtaiding der fünf Stäbe in Pongau 1534.

24 Forest Law Steyr (Waldordnung in Steyr) 1632.
} 
The system of wood transportation over short distances changed very little for centuries. Knowledge was traditional and handed down from generation to generation. Until the end of World War I, this technology, including the construction of forest roads, remained unaffected by changes in other exploitive industries. Drawing from the experience of supplying troops, the use of cableways (funiculars) was introduced in forestry after World War I. Trucks gradually replaced oxen and horses in timber transportation. Taking advantage of military experience, forest road construction became a central concern after World War II. Skidding facilities eventually became modernized, replacing draft animals with tractors, forwarders, and cable cranes. The further expansion of the forest road network has brought about a reduction in skidding distances, more environmentally friendly road construction methods, and the introduction of more and more sophisticated technology in forestry transportation (Hafner 1979, 247).

With the widespread mechanization of wood transport around the middle of the 2oth century, the traditional period of forest technology in the Austrian Alps has finally ended. Temporary installations such as wooden skidding facilities have led not only to the large consumption of valuable commercial wood in the past, but also caused large clear cuts because of the necessity of concentrated harvesting. Such areas could only be cultivated again under difficult conditions. The development of a network of forest roads encouraged the implementation of ecologically friendly management methods and brought social benefits for the people working in the forest. Through the increasing use of machinery, significant improvements in this work were made possible and workers' long stays in the forest in challenging conditions were no longer necessary.

\section{References}

Akademie der Wissenschaften. 1881 and 1913. Steirische und Kärnthnische Taidinge. 2 volumes. Wien: Braumüller.

Allmann J. 1989. Der Wald in der Frühen Neuzeit. Eine mentalitäts- und sozialgeschichtliche Untersuchung am Beispiel des Pfälzer Raumes 1500-180o. Duncker \& Humblot, Berlin.

Hafner F. 1979. Steiermarks Wald in Geschichte und Gegenwart. Österr. Agrarverlag, Vienna. 
Hafner F., Trzesniowski A. 1994. Holzbringung und Walderschließung. In: Österreichs Wald. Vom Urwald zur Waldwirtschaft: $317-356$. Autorengemeinschaft Österreichs Wald, Vienna.

Johann E. 1968. Waldnutzung in Kärnten unter dem Einfluss der Berg-, Hütten- und Hammerwerke. Verlag des Geschichtsvereins für Kärnten, Klagenfurt.

Johann E. 1979. Der Wienerwald. Die Geschichte der Nutzung eines großen Waldkomplexes im Einflussbereich einer Großstadt. In: Actes du Sympopsium International d'Histoire Forestière Nancy, Bd. 1, 227-249. IU F RO, Nancy.

Johann E. 1994a. Holzerzeugung. In: Österreichs Wald, Vom Urwald zur Waldwirtschaft, edited by Österr. Forstverein: 81-107. Eigenverlag Autorengemeinschaft Österreichs Wald, Vienna.

Johann E. 1994b. Wald und Forstordnungen. In: Österreichs Wald, Vom Urwald zur Waldwirtschaft: 171-189. Eigenverlag Autorengemeinschaft Österreichs, Vienna.

Johann E. 2004. Wald und Mensch. Die Nationalparkregion Hohe Tauern (Kärnten). Verlag des Kärntner Landesarchivs, Klagenfurt.

Koller E. 1970. Forstgeschichte des Salzkammergutes. Österr. Agrarverlag, Vienna.

Koller E. 1975a. Forstgeschichte des Landes Salzburg. Verlag der Salzburger Druckerei, Salzburg.

Koller E. 1975b. Forstgeschichte Oberösterreichs. LWK, Linz.

Lampl J. 1891. Urkundenbuch des aufgehobenen Chorherrnstiftes Sankt Pölten. In: Niederösterreichisches Urkundenbuch. Bd. 1, 1. Teil: I.273. Verein für Landeskunde von Niederösterreich, Vienna.

Oberrauch H. 1952. Tirols Wald- und Waidwerk. Schlernschriften Bd. 88. Universitätsverlag Wagner, Innsbruck.

Stummer R. 2007. Großunternehmen Salzkammergut. Österreichischer Milizverlag, Salzburg.

Unterluggauer J. 1925. St. Leonhard und das obere Lavanttal. Buchhandlung Carinthia, Klagenfurt.

von Hornstein F. 1951. Wald und Mensch. Waldgeschichte des Alpenvorlandes Deutschlands, Österreichs und der Schweiz. Otto Maier Verlag, Ravensburg. Weeber K.W. 2003. Rom. Das Leben in der Stadt. Patmos Verlag, Ostfildern. Wessely J. 1852. Die österreichischen Alpenländer und ihre Forste. Braumüller, Vienna. Winter G. 1886, 1896, 1909, 1913. Niederösterreichische Weistümer, 4 volumes. Braumüller, Vienna. 